\title{
Face the waves of emotion in the sea of the unconscious: Focusing on the symbolism of the sea and the waves
}

\author{
Ji So Hyun ${ }^{*}$
}

The purpose of this study was to examine the symbolism of the sea and waves, focusing on these symbols in the dreams and sand trays during the female client's sandplay therapy. The client had dreamt about the sea repeatedly since childhood, so her repetitive dreams about the sea were analyzed during the sandplay sessions. She realized that the deep abyss of the sea was linked to her unconsciousness. Through the dynamic fluctuation of the waves, the emotions that she had suppressed became shaken, and it brought out her anger. As becoming aware of her suppressed emotions, she was able to heal herself. The repeated appearance of the sea in the sand trays connected her to the unconscious and led her to integration and wholeness. She made the choice of recharging her energy for love in the sea and returning to her life. The researcher could understand that it was the message of the sea to love herself and her life and live an authentic life of self-care proudly.

Keywords : Sea, Wave, Symbol, Dream, Sandplay

* Professional counselor at GwangNam Middle School 
Journal of Symbols \& Sandplay Therapy, Vol.12 No.1.

\section{I . INTRODUCTION}

The endless dark, blue sea is the beginning and end of the world, grand but distant, silent but dynamic. To some the sea brings peace and quiet, and to others, comfort. Yet for some, the sea is the fierce life itself. The waves, which bring vitality to the sea, are what make the sea the way it is. At times gently rolling and at other times violently crashing, the waves resemble the human feelings of joy, anger, sorrow and pleasure.

The sea frequently appears in sandpictures created by clients during sandplay therapy. The sand and water used in sand trays are the prima materia, or the primitive matter that makes up the earth. The primitive matter holds all that is possible prior to differentiation and development and the sea is a body of water that represents the deeper unconscious (Jang, 2017). The sea contains an unknown unconscious under its vast surface and becomes a place where the psychic encounter with the possibilities of the unconscious takes place (Turner, 2005/2009). It is not easy to encounter the deep inner world connected to the unconscious in everyday life. Thus, the sea that appears in dreams or sandpictures may be a signal that we need to pay attention to the message of the deep unconscious.

This study examines the general significance of the sea and the waves and the different symbols contained within. It will look into the symbolisms that appear in various myths and folktales to understand the contradicting implications of the sea and the waves. It will also explore the symbolic meanings of the sea and the waves that appeared in sandpictures created by Lia and her dreams of the sea. Carl Gustav Jung (1964/1996) said that the individual is the only reality and that the further we move away from the individual toward abstract ideas about Homo sapiens, the more likely we are to fall into error. He argued that the interpretation of symbols should only be made within the context of the individual's entire life. The sea and the waves contain extensive and numerous symbolic meanings. Although the study examines only a single client, it holds significance in that it seeks to gain a deeper understanding of the symbolism of the sea and the waves within the context of the individual. 


\section{П. SYMBOLISM OF THE SEA AND WAVES}

\section{A. Meaning of the Sea and Waves}

\section{General meaning}

The Greek philosopher Thales (B.C. 624-545), known as the "Father of Philosophy" for his objective and in-depth exploration of the fundamental principle of all things, described the origin of space and nature with water. Lao Tzu, the Chinese philosopher known to have lived during the Warring States period, wrote in Chapter 8 of his work Tao Te Ching, "The highest good is like water. Water knows how to benefit all things without striving with them. It stays in places loathed by all men. Therefore, it comes near the Tao" (Doopedia, 2020). The French philosopher Gaston Bachelard (1884-1962) emphasized the purifying aspect of water. Water symbolizes purity for its transparent and reflective qualities and for its ability to purify the body. As an example, characters in myths become younger after taking a bath in clean, fresh water. These scenes indicate not only the purifying aspect of water but also a longing for healing. Furthermore, water is an element that is related to depth. The deeper a pool of water is, the more it contains the properties of darkness. Therefore, water is also related to death.

The sea is a body of saltwater that covers three-fourths of the earth's surface. It is called

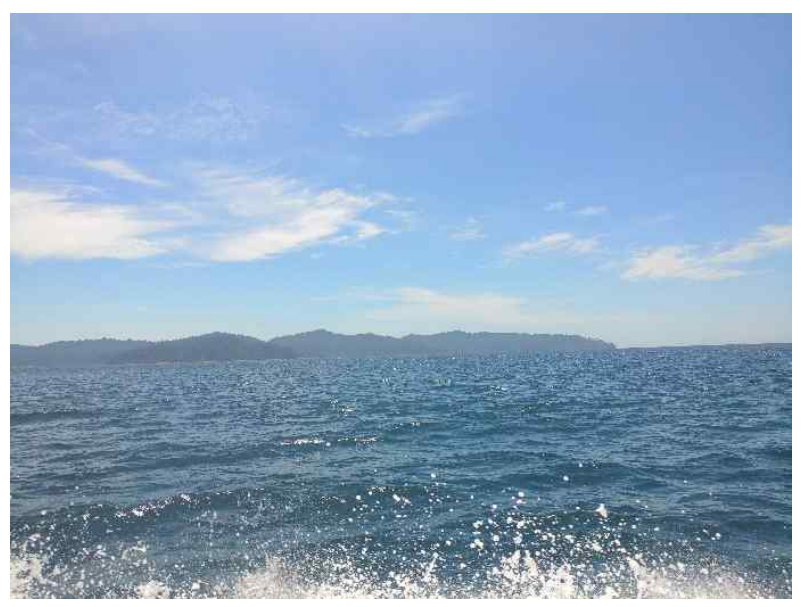

Fig 1. The sea and waves

Source: Photographed by author 
Journal of Symbols \& Sandplay Therapy, Vol.12 No.1.

"hae-yang" in Korean. Hae stands for the deep and dark color of the sea, and yang is for the broad and lengthy appearance of the sea (Doopedia, 2020). The unfathomable blue shade and extensiveness of the deep, dark sea with an endless horizon bring awe to the human being.

The waves are what bring unlimited vitality and liveliness to the sea. Most waves are created by the wind. The heights and intensities of the waves vary, from small waves formed by the gentle breeze to turbulent waves triggered by earthquakes or volcano eruptions in the deep sea, also known as tsunamis. Small waves can always become larger with sustained winds over a long period. In other words, the size of the waves depends on the speed and duration of the wind and the distance it traveled. Thus, a stronger wind that has traveled a long distance is prone to create larger waves. There are also waves created by a surge due to storms or earthquakes, and waves formed by typhoons (Yoon, 2009).

\section{Symbolic significance}

The sea brings to mind unlimited freedom and courageous adventures. At the same time, it indicates unfathomable depth (the unconscious). Vigor and fear lie in the vastness of the sea (Fontana, 2010/2011). The sea symbolizes maternity, feelings, and the unconscious and represents unlimited freedom, joy, vitality, regeneration, tranquility, loneliness, the womb of the earth, the great maternity, the Great Mother and women. Water is the source of life and the sea represents originating water. Thus, the sea symbolizes chaos, endless movement, and the origin of life. It is a symbol of abundance and fertility, and at the same time, a symbol of death (Lee \& Aoki, 2017).

Water is characterized as still and quiet, while the sea is characterized as dynamic and rhythmic. The dynamism of the sea comes from the ebb and flow of the tide induced by the moon and the waves induced by the wind. The waves symbolize permanency accompanied by change and perpetuity in which each moment is clearly pronounced (Yang, 1992).

The quiet and soft waves bring a sense of stability and peace, but the huge and rough waves bring a sense of fear. The fear developed into belief and people prayed to the dragon king asking for health, long life and prosperity. Startled by the power of the rough waves, the people prepared food and offered them in worship. In this case, the waves symbolize fear, 
anxiety and danger (Jeong, 2005).

The wind that creates the waves on the sea symbolizes the breath of the universe and the power of the spirit that sustains life and protects against division. That is why the wind is associated with things such as straps, strings and nets. The wind connects different worlds and all things that exist in this world. At the same time, it also represents things that the hand cannot grasp, things that are immaterial and hard to keep in place (Cooper, 1978/2007). As such, the wind symbolizes the energy of the skies, or the breath of the universe. While soft wind is described in terms of human virtue, rough sandstorms or wandering wind are considered symbols of immorality (Doopedia, 2020). The wind symbolizes suffering in the term "storms of life," and the waves created by the wind are continuously moving water that symbolize the ups and downs and changes in life. They also represent illusions, vanity, and unrest (Cooper, 1978/2007).

\section{B. Symbolism of the Sea and Waves in Myths and Folktales}

Nereus is a sea god in Greek mythology. He is the god of the quiet sea. He is a gentle, wise and honest god who does not know dishonesty. For these traits, he is called the "old man of the sea." Nereus is kind and is a truthful and fair god who does not lean toward any one side. He has the power of prophecy and can transform his appearance in any way he likes. According to the ancient Greek poetry Theogony written by Hesiod, Nereus is the warm-hearted firstborn between the sea Pontus and the earth goddess Gaia. He later came to symbolize the quiet sea. Nereus has 50 beautiful daughters, known as the Nereids, with Doris, the daughter of Oceanos, a god of the oceans. The Nereids live in the palace of Nereus in the depths of the sea, riding on dolphins or swimming in the waves with their long hair floating around them. The Nereids are sea nymphs, known to symbolize the wavering flow of the sea (Encyclopedia of the Characters of the Greek and Roman Mythologies, 2020).

While Nereus is the god of the quiet sea who protects sailors, Poseidon is the god of the vehement sea with angry waves like those that fluctuate in a storm. Poseidon is the god of the sea, earthquake and the sudden wind and is commonly symbolized by the dolphin or horse. The trident of Poseidon symbolizes his power and is used to create waves in the sea and earthquakes 
Journal of Symbols \& Sandplay Therapy, Vol.12 No.1.

on earth. It also makes the rivers or springs of water swell and creates new islands (Wikipedia, 2021). Earthquakes and volcano eruptions that shake the earth bear the vehement characteristics of Poseidon. At one moment the sea is as calm as a lake, but the next moment the wild wind rages and a mountainous tidal wave crashes in, devouring everything. Poseidon is known to act on spontaneous and impulsive momentary emotions and to be impatient, straightforward, erratic and sentimental. The unpolished, rough and crude aspects of Poseidon represent the primitive powers of Mother Nature, where storms, raging billows, tidal waves, earthquakes and volcano eruptions take place (The Greek and Roman Mythologies and Western Culture, 2020).

Poseidon fell in love with Amphitrite, one of the 50 daughters of Nereus who was dancing in the sea. He asked Amphitrite to marry him, but she rejected him. Poseidon continued to pursue her, employing help from sea creatures. In the end, Amphitrite was persuaded by the dolphins and married Poseidon. Amphitrite, who symbolizes the beauty of the sea, became Poseidon's wife and the queen of the sea. Amphitrite is also known as the goddess of the quiet sea and the symbol of safe passage that protects even against rainstorms. This is because she is the only one whose voice can soothe Poseidon's anger and make him fall into a deep sleep, thereby calming the sea(Daum Encyclopedia, 2021).

Poseidon had several affairs with other women after he was married. While Hera released her anger by persistently tormenting the women whom Zeus had extramarital relationships with

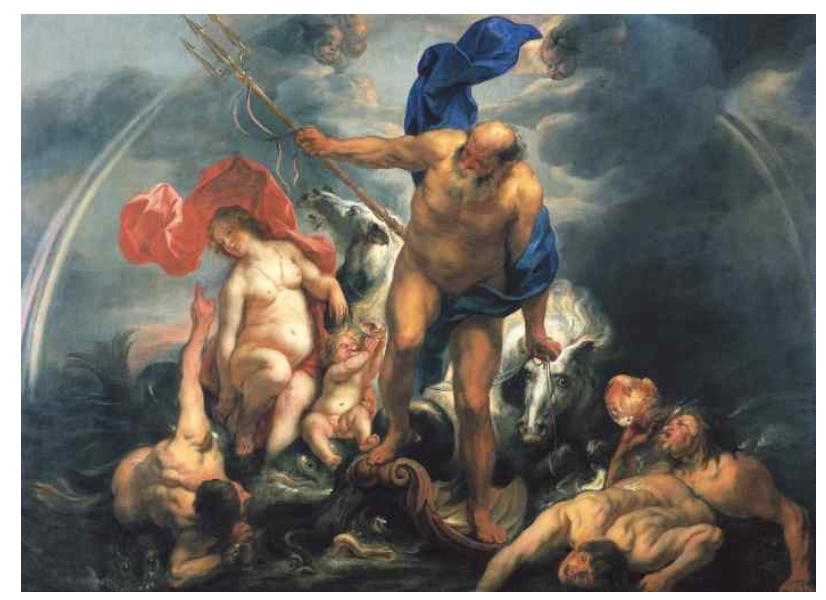

Fig 2. Jacob Jordaens 〈Neptune and Amphitrite in the Storm〉

Source: https://commons.wikimedia.org/wiki/File:Jacob_Jordaens Neptune_and_Amphitrite_in_the_storm,_1644.jpg 
and their children, Amphitrite overturned the sea with raging anger. This may be related to the etymology of the name "Amphitrite," which includes meanings of "raging anger" and "outcry."

Now let's turn to Scylla and Charybdis, two monsters in the Greek and Roman mythologies who symbolize the destructive power of the sea. In Odysseia, Scylla and Charybdis are portrayed as monsters who represent dangerous sea currents or twisters.

There are several known stories on Scylla. In one story, Poseidon fell in love with Scylla because she was very beautiful. Amphitrite became jealous and poisoned Scylla. In another story, Glaucus fell in love with Scylla at first sight and went to Circe in search of a love potion that he could use to win her heart. However, Circe also fell in love with Glaucus and handed him poison instead of a love potion. The poison turned Scylla into a monster with six heads with four eyes and three rows of sharp teeth, with a neck as long as a snake (Liu, 2018/2020). The beautiful maiden Scylla turned into a snake-like monster from Circe's ill-intended trick. Since then, she lived in a cave located on a high cliff and stretched her long neck from the six heads to snatch and prey on sailors passing nearby.

Charybdis was also a monster who lived near the surface of the sea. Three times a day, Charybdis created a whirlpool, sucked in the seawater and belched it out again. Boats floating

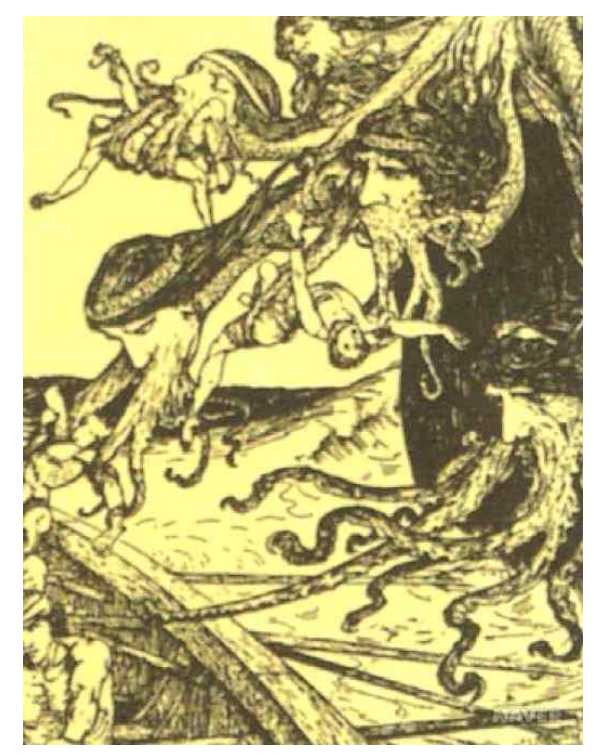

Fig 3. Scylla snatching the sailors

Source: https://terms.naver.com/entry.nhn?docId=1832930\&cid=41869\&categoryId=41869 
Journal of Symbols \& Sandplay Therapy, Vol.12 No.1.

nearby were sucked into the whirlpool, and even the sea god Poseidon could do nothing about it. Odysseus sent out his men to closely guard and search the area where these frightening monsters appear, but six of them were taken away by Scylla. It was the most frightening and horrible scene that Odysseus had ever witnessed. He could do nothing but helplessly watch his men scream and die. The story reflects the terror and fear human beings have for the sea (Bulfinch’s Mythology, 2020).

A portrayal of the powerful force and destructive strength of the sea that human beings cannot control is also found in the Korean folktale "The Tale of Shim Chong." In the story, a monk tells Shim Chong's blind father that he will see again if he gives 300 sacks of rice as an offering to Buddha. He promises to make the offering. But when he returns home, he realizes that there is no way he will keep the promise. All he could do was sigh. He told Shim Chong about what happened. Meanwhile, some sailors were looking for a maiden to offer as a sacrifice to calm the ferocious sea with high waves. The only way to pacify the angry waves and sail across the sea was to offer a maiden as a sacrifice. Shim Chong volunteered to give herself as a sacrifice in return for 300 sacks of rice. Shim Chong arrived at the sea of Indangsu as she had promised, covered her head with her skirt and threw herself into the fierce dark-blue water. The waves then stopped and the sea became calm (Ko, 2006). In this story, the sea represents a force too powerful for man, chaos and destructive power (Lee \& Aoki, 2017).

The sea and its fierce waves symbolize suffering and hardship and are often portrayed to bring fear to the human being. However, there is also a story about a person who faces that suffering and fear. In the Korean folktale "Seoksoong's Journey in Search for Good Fortune," the main character Seoksoong is a house servant who lost his parents as a child. Seoksoong had little hope that he would be able to overcome poverty. Frustrated with his circumstances, he one day decided to end his life by drowning in a stream. An old man appeared and scolded him, and told him to go to the Western Island of the Western Sea to ask for good fortune. So Seoksoong took off on a long journey in search for the Western Island of the Western Sea. With help from several people along the way, Seoksoong finally arrived on the Western coast. He saw the Western Island sitting in the middle of the far sea but did not know how to cross the deep water. Just then, he saw a boat about to sail off and asked for a ride. He was finally on his way toward the island when a strong wind blew and the boat was on the verge of 
capsizing. In the middle of the confusion, a huge serpent suddenly appeared. Seoksoong stayed calm and rebuked the serpent. The serpent complained to Seoksoong about his circumstances, telling him that he wanted to become a dragon but couldn't. Seoksoong listened to the serpent's story and promised that he would tell his story to the dragon king when he arrives at the Western Island. Pleased with his words, the serpent took Seoksoong to the Western Island. Having finally arrived at the Western Island after all the trouble, Seoksoong met the dragon king and told him about all the things that happened. In the end, he returned not only with a fortune ticket but also a wife (Cultural Archetype Encyclopedia - Characters in Korean Folktales, 2020). As such, the sea represents human struggling and hardship but at the same time it also conveys the wisdom and courage of the human being that faces and deals with fear without running away.

Last but not least, another aspect of the symbolism of the sea and the waves can be found in the Greek goddess Aphrodite. Aphrodite is a goddess of beauty and love and one of the twelve gods and goddesses of Mount Olympus. According to Hesiod's Theogony, Aphrodite was born from the foam produced when Uranus's genitals, cut off by Cronus's sickle, fell into the sea and the semen mixed with seawater. The word "foam" is "aphrós (aфpós)" in ancient Greek, and "Aphrodite" means "woman risen from the foam." Aphrodite is also often referred to as "Anadyomene," which stands for "woman risen from the sea" (Encyclopedia of the

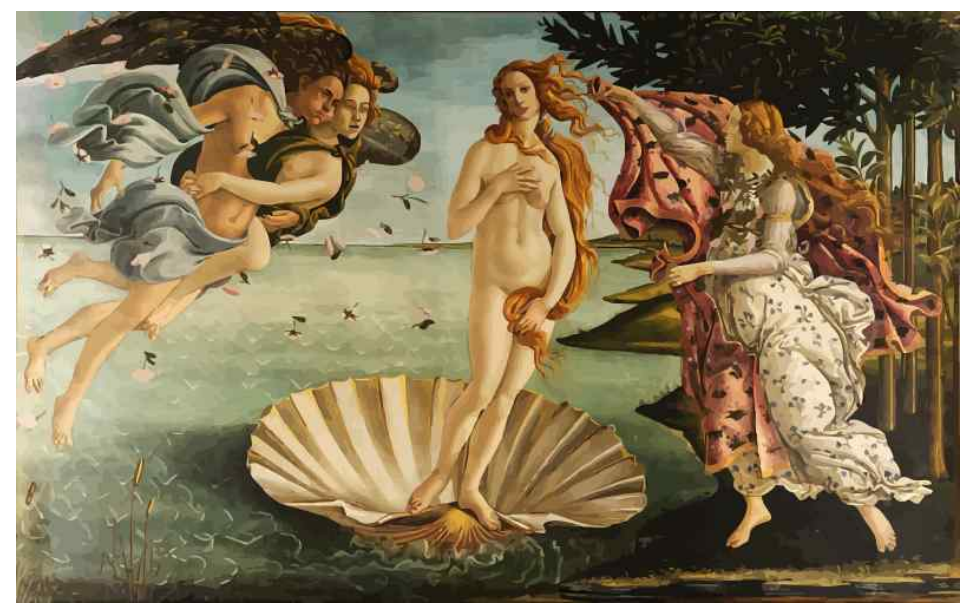

Fig 4. Sandro Botticelli 〈The Birth of Venus〉

Source: https://commons.wikimedia.org/wiki/File:La_nascita_di_Venere_vectorized.png 
Journal of Symbols \& Sandplay Therapy, Vol.12 No.1.

Characters of the Greek and Roman Mythologies, 2020).

Aphrodite is a goddess born from the seeds of the sky that were nurtured in the womb of the sea. She emanates a profuse energy of abundance, grace and vitality. She embodies the aspects of the sky that indicate purity, innocence and peace and the aspects of the earth that symbolize abundance and fertility. Aphrodite is a goddess who incorporates these polar aspects in a natural and highly sophisticated way. She integrates the two polar aspects of the sublimity of the skies and fertility of the earth, the sacred and the profane, the wilderness and civilization, and the spirit and body. Giggling laughter, a sweetness that can melt anything, playful hugs and kisses and joyful merrymaking are all things of the goddess. Wherever Aphrodite is present, the area is filled with the feeling of complete innocence and softness that can be felt from her baby-like face, warmth and coziness, and lightness and humor that uplift the air and mood. A fresh scent like that of a wildflower, the warmth of natural contact, and the innocent happiness produced by a mixture of lighter air, verbal amusement and the art of seduction are all gifts of the goddess. An attitude that respects Aphrodite spreads beauty to one's surroundings because it leads others to discover their inner beauty and express it freely. The goddess of beauty is pleased when beauty is not kept to oneself but is nurtured and expressed. A life that expresses beauty is honest, and an honest person is beautiful. Life is a process of discovering the beauty hidden within oneself and sharing it with the world so that the world will be filled up with beauty (Ko, 2006).

We have so far looked at ancient myths that contain symbolism of the sea and the waves. Nereus was the god of the quiet sea, and his beautiful daughters, the Nereids, symbolized the quiet tide. Poseidon was emotionally driven, passionate and storm-like, and went to great lengths to earn the affection of his wife, Amphitrite. Scylla was once a beautiful woman before she turned into a destructive sea monster from jealousy, and Charybdis was a monster who created whirlpools in the sea. We also looked into the story of Shim Chong, who demonstrated her love and sacrifice by jumping into the fierce sea, which could only be tamed with the offering of a maiden as a sacrifice, and was reborn in death. We met Seoksoong, who confronted the suffering and hardships of the rough waves with wisdom and courage and in the end obtained good fortune and a loving wife. Finally, we explored the birth of the goddess of 
love Aphrodite, born in the womb of the sea from the seeds of love from the sky. Through the story of Aphrodite, we contemplated on life that fills up the world with beauty by discovering and sharing the beauty of the inner world.

\section{Significance of the Sea and Waves in the Sand Tray}

Lia is a working mother in her mid-forties with two children. Lia returned to her studies about ten years ago when she was in her early thirties and found a job after graduation. She is very diligent and makes the best effort in everything, but she has an excessive tendency to look after her family or do well at work rather than look after herself. It seemed much of her energy was exhausted and spent. Lia told a story about her father, who did not look after her family and spent his entire life going after his dream and passion or someone else other than his wife and family. She added that when things did not go in the way he wanted, her father would impulsively express his anger to his family. Because she experienced how her father's selfish ways and irresponsible life gave a hard time to her family, Lia said she was determined to diligently look after her family and be a good parent. As a child, Lia lived in a seaside village before she moved to the city with her family due to economic struggles. She has longed for the sea ever since. She mentioned that she had repeated dreams about the sea since she was a child, so an analysis of those dreams was conducted during the sessions. Sandplay therapy is based on the theories of analytical psychology and thus places importance on the analysis of dreams as a process of exploring the human unconscious. Often, dreams reveal profound symbols of the human unconscious (Hwang, 2020). This study seeks to analyze the symbols discovered during sessions with Lia, focusing on her dreams of the sea and sandpictures that portray the sea.

\section{Dreams of the sea}

Lia said that in her repeated dreams, she was wandering around looking for the sea.

"In the dream, I am at the beach. I move from one black rock to the next to get closer to the sea. The waves break under my feet. Oh, it's the sea! I sit and watch endlessly as the waves waver, creating 
Journal of Symbols \& Sandplay Therapy, Vol.12 No.1.

white splashes as they break. Tears are rolling down my face. Then the sun starts to set and night is coming. I have to return home before it gets completely dark. I am sad to go, and I want to stay a bit longer, but I shake it off and get on my feet. It is getting dark, and I get on a bus that will take me home."

[Fig 5] is a sandpicture created by Lia. A female figure is sitting by herself on a rock and staring at the sea. There is a huge mountain on the front-right side of the sand tray, and the sea is spread toward the back-left.

Recalling her dream, Lia said that at times when she feels lost about what she needs to do, where she needs to go, and even what she feels, as if all senses of life are paralyzed, and when she feels overwhelming loneliness from the feeling that she has no compass or milestone in life, she visits the sea. Lia said that when she stands before the vast and endless sea and listens to the sound of the waves, a world that she had never met before opens. It is as if something that has been asleep for thousands or tens of thousands of years has awakened, and Lia said she enjoys the moment with the sea, an ancient archetype. The sound of the waves delivered by the sea and the scent of the sea delivered by the wind soothed her mind, and she said she feels comforted when she talks to the sea.

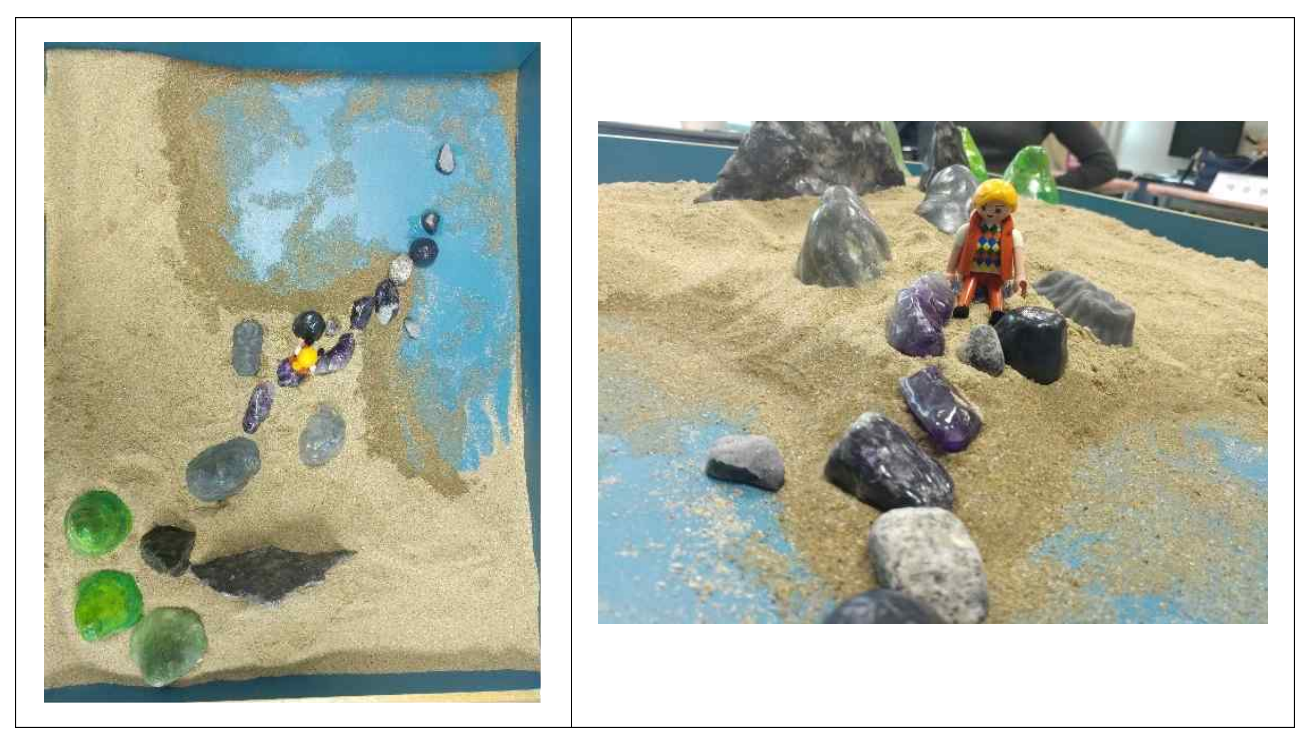

Fig 5. Sandpicture depicting dream of the sea, created during dream analysis 
Turner (2005/2009) said that the sea in sandplay therapy is a place of arrival and departure of psychic characteristics. Rugged or bumpy coastlines have different meanings from smooth coastlines. A protruding or peninsula-shaped coastline indicates psychic progress toward change. It leads to penetration toward a deeper place, which augments the possibilities for psychic development. In Lia's sandpicture shown above, small and big rocks make a line toward the depths of the sea. This indicates that Lia's inner world should be connected to the unconscious aspect of the deep sea.

Looking closely, the boundary between the sea and sand in Lia's sandpicture has traces of turbulent waves. Although Lia did not use water in the sandpicture, the sea looks astonishingly liquid due to the shades of light. This makes the woman sitting alone, silent and lost in her thoughts, seem lonelier and more depressed from the back.

People are alone when they face their own selves. When we are born, the umbilical cord of a relationship is broken, and life becomes a process of building relationships by weaving meaning. In that sense, building relationships is something that everyone knows about, therefore becoming meaningless and turning into an old "daily trap." Whether it is from a disconnection of contact or excess of contact, Lia has to withstand this existential solitude. She needs to face the existential solitude that wakes her up from the "sleep" induced by things she used to accept blindly, including her parents' opinions, generational values, societal systems and customs, marriage systems and childhood trauma. Lia's "existential derailment" that comes from realizing that she is alone and that she should take off the heavy burden placed on her by the collective culture is very natural and something to be welcomed. People who discover themselves seek to stand alone and be free. Therefore, Lia needs some time on her own.

The beach is where the two worlds of earth and sea meet, which symbolize the two territories of the human psyche, consciousness and the unconscious. Therefore, a dream of the beach could be an invitation to become familiar with the unconscious and explore the unconscious territory (Ackroyd, 1993/1997). The sea sends a signal from the deep inner world to tell Lia, who is focusing only on fulfilling the roles given to her in the consciousness territory, that she needs to spend time looking after herself. However, in her dreams Lia stands up to go home, although she is reluctant to do so. In both the outer and inner worlds, failing 
Journal of Symbols \& Sandplay Therapy, Vol.12 No.1.

to keep balance and leaning on one side can hinder the integration of factors of the unconscious (Lee, 2018). Although it seems that she needs to spend more time sitting and thinking alone in silence and talk to the Self, she gets on the bus to return home so that she can take care of her family.

Lia expressed feelings of depression and anger during the dream analysis as she looked at the traces of turbulent waves in her sandpicture. She discovered that although she knew natural feelings could not be defined as good or bad, reasonable or unreasonable, she still believed that depression and anger are inappropriate feelings for a "proper woman" and should never be expressed. She said that when she felt anger, she would remain silent, swallow the anger with her tears, become self-critical or bury the anger under a scar. When we identify excessively with a persona tailored to social standards, various feelings get suppressed and our inner world sheds tears (Sung, 2015).

Lia said she felt a wave of emotions rushing in as she sat looking at the endless sea. The movement of the waves was like the wavering of her emotions. They shook up the pent-up anger that had been buried in silence throughout her life and released it. The anger was about her life. She was exhausted from using all her energy to maintain the "acquired persona" as a good daughter, a good mother, a good wife and a career woman, which led her to focus on taking care of others while neglecting herself. When emotions and psyche excluded and suppressed by the persona of the good are detached from consciousness and gain traits of the unconscious, a danger of division and exclusion from the wholeness of oneself occurs (Rhi, 1998).

During the dream analysis process Lia focused on the moment she gathered her thoughts and feelings while sitting alone on the beach and facing the waves. She said that before the sea, she could carry out the rusty feelings that she could not share with anyone in everyday life. As she re-experienced her anger and sadness and faced the negative emotions that had been buried for many years, Lia was able to look back on her life and see how hurt she was and how she had been striving to meet the excessive demands and expectations of her parents.

Just as the turbulent storm purifies the sea, making it greener and calmer, facing one's anger and experiencing a whirlwind of suppressed emotions takes away old anger and fills it up with energy for a new start. Love is the driving force that leads one to fill up with new energy 


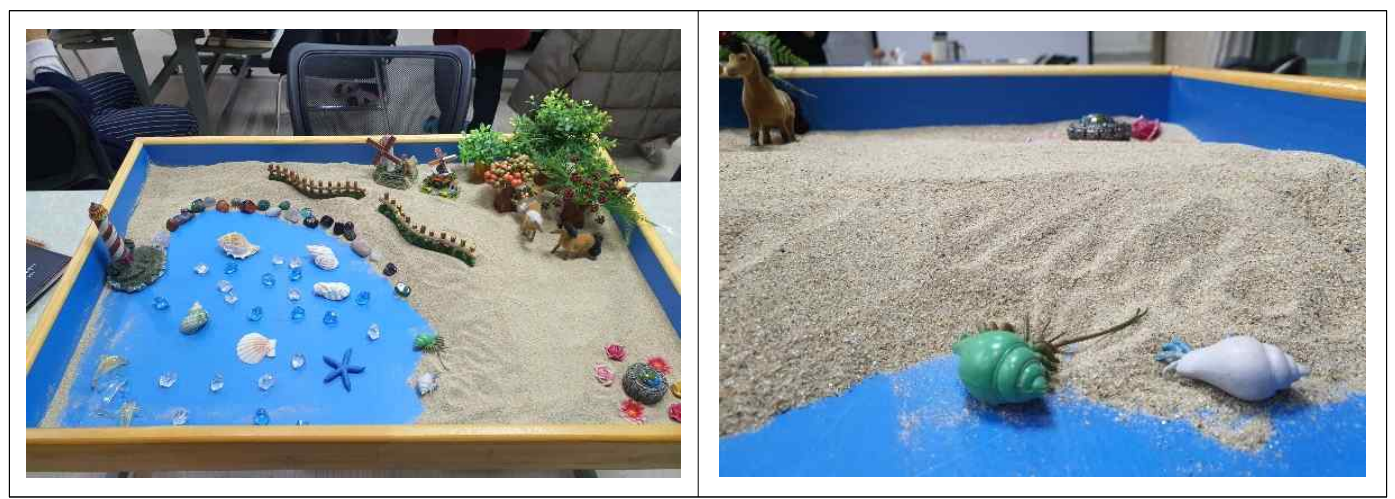

Fig 6. Sandpicture of a windy hill and sea

and return home. The characteristics of the goddess of love and beauty Aphrodite enrich everyday life and fill it up with refined beauty, which is the goddess's work of art and love (Ko, 2006). It seems Lia's dream is about choosing to let go of the things that have been built up and filling the space with new energy before readily returning to everyday life. It is a message telling her to go back to a life of tending to and genuinely taking care of herself. It seems to be telling her about a life that recognizes, expresses and freely chooses what is most important to her and readily taking responsibility for it. It seems to be saying that the person who can heal the scars of the past is herself and that there are loving people who love her and waiting for her.

\section{The sea in the sand tray}

The following are photos of a sandpicture created by Lia during sandplay therapy:

"It is a windy hill. Because it is so windy, I wanted to build a high hill with the sand. I also decided to add windmills. I think it will be refreshing to ride a horse on the high, windy hill. There is an excellent view of the sea below. Right now, the sea seems calm but because it is such a windy area and high waves can crash in at any moment, I added a fence. A mother dolphin is playing with her two baby dolphins far out in the sea. Two hermit crabs are climbing up onto the beach just now. They are easily startled and will hide inside their shells to the smallest disturbance, but right now, they are determined to get to their destination. Something precious and valuable lies there. I think it would be a 
Journal of Symbols \& Sandplay Therapy, Vol.12 No.1.

very long journey for the hermit crabs, but I think they will steadily go on their way."

Lia created a sandpicture of a windy hill on the beach. The wind is the breath of the universe and symbolizes the connection of different worlds and connection to all things alive, such as strings, ropes and bridges. She used the sand to create a high hill with a steep slope, with a sea spread out underneath. The two horses that were running down the hill in the wind are now resting underneath a tree. It is interesting that the two horses are not running at full speed but rather resting under the tree. Lia had always been running like a horse with a level of passion unmatched by others. She tried not to harm others with her selfish desires and to live an independent and autonomous life. When Lia first came to the therapy room the researcher asked what she was expecting from the therapy experience. She answered, "Now, I would like to do something that I want to do." Her answer resonated with the researcher because it showed that she had been doing nothing but running forward throughout her life without resting up until the point.

Under the house on top of the hill, Lia lined up rocks along the coastline. The rocks became part of a double, or triple, defense system along with the fence and the high hill. It seemed that although she would look down on the sea in everyday life, she wanted to put up two to three layers of protection in case the waves were too high. Although the sea appears calm, Lia wanted to protect the house from high tidal waves that could suddenly crash in.

As she was slowly going over and examining the sandpicture she had completed, Lia pointed out the hermit crabs placed a little under the center of the tray. The hermit crabs had just crawled out from the sea and were heading toward a treasure box decorated with flowers. She said that although it may be a long journey for the hermit crabs, they would diligently make their way forward. A crab indicates resurrection and regeneration. It also symbolizes movement between the consciousness and the unconscious because it moves between water and land (Lee \& Aoki, 2017). The hermit crab lives in shells of gastropods as its home. As it grows, the crab abandons the old shell for a larger shell. That is why these crabs are called "hermit crabs." It seemed that Lia was not expressing her honest emotions to avoid a life like that of her father, who was impulsive, self-centered and gave her family a hard time with love 
and art. Just like a hermit crab that carries around a large shell and hides in it, Lia has been hiding her feelings and lived life as a hermit. Hermit crabs need to move to a larger shell as they grow, and Lia's journey to the sea seemed to have been a journey to abandon the small shell and find a larger one.

It seemed that even though Lia set up two to three layers of protection against the waves, the unconscious of the deep sea had sent out the small hermit crabs as messengers to inform the existence of the treasure box decorated with flowers placed on a corner of the sand tray, which symbolizes the Self. It appeared as if the small hermit crab was asking to quickly open the treasure box with the sparkling jewels, deep within the inner world. The presence of the treasure box, which symbolizes the Self, seemed to represent the beginning of Lia's journey toward recognition of the Self. Recognition of the Self is a process of recognizing the contents of the unconscious. Recognition is not only an intellectual process but also emotional discernment, which makes it a process of "realization" (Sung, 2015). The journey of the hermit crabs will become a journey toward recognition of the Self and realization, which would be the start of a long journey toward an individuation process.

While studying the case of Lia and the symbolism of the sea and the waves, the researcher ran across an old drawing. It was "The Great Wave off Kanagawa," one of the most famous

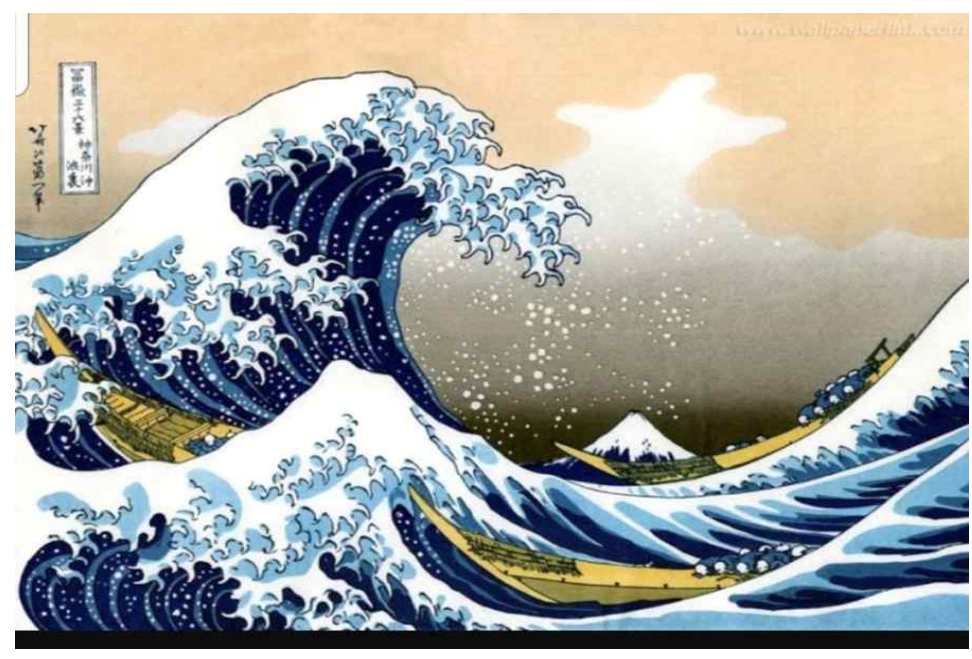

Fig 7. Katsushika Hokusai 〈The Great Wave off Kanagawa〉

Source: https://commons.wikimedia.org/wiki/File:Tsunami by hokusai 19th century.jpg 
Journal of Symbols \& Sandplay Therapy, Vol.12 No.1.

drawings from the series Thirty-six Views of Fuji by the Japanese artist Katsushika Hokusai (1760-1894).

The high waves that seem just about to devour almost look like the claws of a fierce beast. They display tremendous force, strong enough to sweep up everything on sea. There are people crouching their bodies as they hold onto the ships that seem desperately small compared to the monstrous waves. But rather than shaking in fear or being terrified, the people seem to know that this shall soon pass, and look as if they are moving together with the movement of the angry waves. The mountain in the distance that looks like a part of the waves is Mount Fuji, which seems all-knowing. It knows that the turbulent sea will become calm again, and when it does, it will be in a deeper, darker blue that embraces and nurtures life. It also seems to know that human beings who overcome the angry waves by lowering their posture will become more disciplined, developed and filled with energy. Hokusai's art piece brings to mind the case of Lia, who will learn to love herself more deeply from the encounters with the angry waves, fluctuating emotions and the deep inner Self.

\section{CONCLUSION}

This study was motivated by an attraction to the sea and waves. It was an opportunity to recognize the meaning of the symbolism of the sea and the waves and learn about the meaning of the message sent by the sea of the unconscious. It was an opportunity to think about Lia's experience when she visited the sea in times of hardship. On days she could not physically visit the sea, she would search for it in her dreams and stare at it endlessly. The study looked into what the sea and waves mean to Lia and what it is trying to tell her.

Whenever Lia was caught up in fulfilling the roles given to her by others in everyday life and not living her own life, ignoring the voice of her inner world, the depths of the unconscious may have led her to the sea. On days when even that voice was ignored, Lia found herself looking for the sea in her dream. Lia was living in a world of consciousness and the sea became a field that supplied Lia with the possibilities and energy of the unconscious (Eom, 
2014)

The word "symbolism" comes from the Greek term "symbolon," which means "thrown together." In its original definition, symbolism is about one half of a broken stick or coin validating the identity of the other half, vice versa. Symbolisms lead us to the parts that have disappeared from our wholeness and connect us to our fundamental wholeness (Edinger, 1972/2016). Both the external and internal worlds of the psyche appear in a sandpicture. As images from the unconscious are projected onto the sand tray, the unconscious becomes conscious and the client becomes closer to wholeness and experience the feeling of integration in the inner world (Jang, 2017). It seems the sea that continued to appear in Lia's sandpictures was trying to lead Lia to wholeness and integration through symbolism.

Jung (1964/1996) said that symbolisms have an "unconscious aspect" that is never precisely defined or fully explained, and that one cannot hope to define or explain it. He said that as the mind explores the symbol, it is led to ideas that lie beyond the grasp of reason.

Lia was buried in the roles imposed on her in everyday life, which kept her from truly taking care of herself. As she was being depleted, the deep abyss of the sea called on Lia to stop and stay in the depths of the inner world. The dynamic fluctuations of the waves aroused withdrawn emotions that have been swallowed and suppressed and drove out the anger disguised as depression. Lia recognized that it was she who gave herself the scars, not anyone else. This led her to realize that she can treat her scars and heal.

As becoming aware of her suppressed emotions, Lia will now be able to let go of the hurtful emotions and fill up the space with the innocence, lightness, freedom and loveliness of the goddess of love Aphrodite. Lia makes the decision to fill up a new energy of love at the sea before returning to everyday life. That may be the message of the sea: love yourself and your life, and confidently live an authentic life by taking genuine care of yourself.

\section{References}

Ackroyd, E. (1993/1997). A dictionary of dream symbols. (Translated by Kim, B-J.). Seoul: Korea Psychotherapy Institute. 
Journal of Symbols \& Sandplay Therapy, Vol.12 No.1.

Cooper, J. C. (1978/2007). An illustrated encyclopaedia of traditional symbols. (Translated by Lee, Y-K.). Seoul: Kachi.

Edinger, E. F. (1972/2016). Ego and archetype. (Translated by Jang, M-K.). Seoul: Hakjisa.

Eom, M-Y. (2014). Water: A symbol of potential. Journal of symbols \& sandplay therapy, 5(1), 59-71.

Fontana, D. (2010/2011). The new secret language of symbols. (Translated by Gong, M-H.). Seoul: Sungkyunkwan University Press.

Hwang, H-R. (2020). A research on the turtle's symbolic ambivalence and its role as a spiritual guide for individuation entrance. Journal of symbols \& sandplay therapy, 11(1), 99-145.

Jang, M-K. (2017). Analytical psychological sandplay therapy. Seoul: Hakjisa.

Jeong, J-I. (2005). A study of formative ceramic art with images of waves as the subject matter. (Unpublished Master's dissertation). Ewha Womans University, Seoul, Korea.

Jung, C. G. (1964/1996). Man and his symbols. (Translated by Lee, Y-K.). Gyeonggi: The open book. Ko, H-K. (2006). Why did the fairy leave the woodcutter. Seoul: Hanibook.

Lee, K-M. \& Aoki, D. (2017). Dictionary for symbol. Seoul: Hakjisa.

Lee, Y-R. (2018). Symbolism of mirrors as the first step of individuation and self-awareness. Journal of symbols \& sandplay therapy, 9(1), 39-52.

Liu, X. (2018/2020). Grotesque supernatural beings. (Translated by Lee, J-H.). Gyeonggi: HyundaeJisung.

Rhi, B-Y. (1998). Analytical psychology; C.G. Jung's thoughts on mind. Seoul: Ilchokak.

Sung, E-K. (2015). Tears: Symbol of healing towards the individuation. Journal of symbols \& sandplay therapy, 6(2), 47-60.

Turner, B. A. (2005/2009). The handbook of sandplay therapy. (Translated by Kim, T-R., et al.). Seoul: Hakjisa.

Yang, S-M. (1992). Dictionary of Korean Culture Symbols I. Seoul: Dong-A

Yoon, K-C. (2009). A great travel to the sea. Seoul: Purungil.

\section{Web sites}

“Amphitrite" Daum Encyclopedia. (2021, Mar. 24). Retrieved from https://100.daum.net/encyclopedia/view/b14a4098a

"Aphrodite - The 12 Gods and Goddesses of Olympus" Encyclopedia of the Characters of the Greek and Roman Mythologies. (2020, Oct. 25). Retrieved from https://terms.naver.com/entry.nhn?docId $=3397989 \&$ cid $=58143 \&$ categoryId $=58143$

"Nereus - The God of the Sea" Encyclopedia of the Characters of the Greek and Roman 
Ji So Hyun / Face the waves of emotion in the sea of unconsciousness: Focusing on the symbol of the sea and the waves

Mythologies. (2020, Oct. 25). Retrieved from

https://terms.naver.com/entry.nhn?docId=3397678\&cid =58143\&categoryId =58143

"Poseidon - The sea of storms and billows" The Greek and Roman Mythologies and Western Culture. (2020, Oct. 20). Retrieved from

https://100.daum.net/encyclopedia/view/155XX51600012.

"Poseidon" Wikipedia. (2021, Mar. 27). Retrieved from

https://en.wikipedia.org/wiki/Poseidon

“Scylla and Charybdis” Bulfinch's Mythology. (2020, Oct. 20). Retrieved from

https://terms.naver.com/entry.nhn?docId=1832930\&cid=41869\&categoryId=41869

"Sea" Doopedia. (2020, Oct. 25). Retrieved from

https://www.doopedia.co.kr/doopedia/master/master.do?_method=view\&MAS_IDX=101013000709913

"Seoksoong's Journey in Search for Good Fortune" Cultural Archetype Encyclopedia - Characters in Korean Folktales. (2020, Oct. 25). Retrieved from

https://terms.naver.com/entry.nhn?docId=1783632\&cid=49258\&categoryId=49258)

"The highest good is like water" Doopedia. (2020, Oct. 25). Retrieved from

https://www.doopedia.co.kr/doopedia/master/master.do?_method=view\&MAS_IDX=180116001561874

"Wind" Doopedia. (2020, Oct. 25). Retrieved from

https://www.doopedia.co.kr/doopedia/master/master.do?_method=view\&MAS_IDX=101013000824240

투고일 : 2021. 03. 30

수정인 : 2021. 06. 18

게재확정일 : 2021. 07. 01 



\title{
무의식의 바다에서 감정의 파도를 만나다: 바다와 파도의 상징을 중심으로
}

Face the waves of emotion in the sea of the unconscious:

Focusing on the symbolism of the sea and the waves

\author{
지 소 현 \\ Ji So Hyun
}

\begin{abstract}
$<$ Abstract $>$
The purpose of this study was to examine the symbolism of the sea and waves, focusing on these symbols in the dreams and sand trays during the female client's sandplay therapy. The client had dreamt about the sea repeatedly since childhood, so her repetitive dreams about the sea were analyzed during the sandplay sessions. She realized that the deep abyss of the sea was linked to her unconsciousness. Through the dynamic fluctuation of the waves, the emotions that she had suppressed became shaken, and it brought out her anger. As becoming aware of her suppressed emotions, she was able to heal herself. The repeated appearance of the sea in the sand trays connected her to the unconscious and led her to integration and wholeness. She made the choice of recharging her energy for love in the sea and returning to her life. The researcher could understand that it was the message of the sea to love herself and her life and live an authentic life of self-care proudly.
\end{abstract}

Keywords : sea, wave, symbol, dream, sandplay

* 교신저자, 경기도 광남중학교 전문상담교사 (counsel_ji@naver.com) 
Journal of Symbols \& Sandplay Therapy, Vol.12 No.1.

\section{I. 서 론}

끝없이 펼쳐진 깊고 푸른 바다는 웅장하면서도 아득하고, 고요하면서도 역동적인 세상의 시작이자 끝이다. 바다는 누군가에게는 쉼이자 휴식이고, 누군가에게는 위로이며, 또 누군 가에게는 치열한 삶이다. 그러한 바다에 생명력을 불어넣으며 바다가 바다일 수 있게 하는 것은 파도이다. 파도는 잔잔하게 일렁이기도 하고 세차게 휘몰아치기도 하는 인간의 희로 애락, 감정과 닮아있다.

모래놀이치료 장면에서 만나는 많은 내담자의 모래 상자에는 바다가 빈번하게 출현한다. 모래 상자에서 모래와 물은 지구의 본질적인 요소로서 원질료인 프리마 마테리아(prima materia)이다. 원질료는 아직 분화, 발달하기 이전의 모든 가능성을 내포하고 있는데, 그중 바다는 더 깊은 무의식으로서의 물을 의미한다(장미경, 2017). 바다의 거대한 물 표면 아래 에는 알 수 없는 무의식이 담겨 있으며, 바다는 그러한 무의식의 가능성과 정신적 만남이 이루어지는 장소가 된다(Turner, 2005/2009). 일상적인 삶에서 무의식과 연결되는 깊은 내면 을 만나기란 쉽지 않다. 따라서 꿈이나 모래 상자에 나타나는 바다는 깊은 무의식의 메시 지에 귀 기울이라는 신호일 수 있다.

상징은 원형적 정신의 자발적 산물로서, 인간은 상징을 제조할 수 없으며 단지 발견할 수 있을 뿐이다(Edinger, 1972/2016). 물이 잠재성의 보편적 총체를 상징하며 근원이자 원천 으로서 모든 존재 가능성의 저장소이고(Eliade, 1952/1998), 근원적 관점에서는 영원한 생명력 을, 현상적 관점에서는 변화와 운동을, 기능적 관점에서는 정화와 치유를, 문화적 관점에서 는 죽음의 두려움과 공포를 상징한다(장영란, 2013). 이와 같은 물의 상징에 대한 선행연구 를 바탕으로 본 연구에서는 꿈과 모래상자에 반복적으로 출현하는 바다와 파도에 주목하여 그 상징적 의미를 발견해 보고자 한다.

이를 위해 본 연구에서는 우선 바다와 파도의 일반적 의미와 그것이 내포하고 있는 여러 상징을 살펴볼 것이다. 특히 신화와 민담에 나타난 상징성을 통해 바다와 파도의 대극적 의미를 알아보고, Lia의 모래놀이치료 사례에서 꿈과 모래 상자에 나타난 바다와 파도의 상 징의미도 함께 살펴볼 것이다. Jung(1964/1996)에 따르면 개인이야말로 유일한 현실인데, 개 인에서 분리된 인류(Homo sapiens)라는 추상적인 개념을 쫓아갈수록 오류에 빠질 가능성이 크다고 했다. 상징의 해석에 있어서도 개인의 전체적 삶의 맥락 안에서만 해석되어야 한다 고 했다. 바다와 파도는 광범위하고 무척 다양한 상징적 의미를 담고 있다. 단일 사례이지 만 그럼에도 내담자 개인의 맥락에서 바다와 파도의 상징을 깊게 이해해보고자 하는 본 연 구는 그러한 측면에서 의의가 있다. 


\section{I. 바다와 파도의 상징성}

\section{1. 바다와 파도의 일반적 의미}

만물의 근본 원리를 객관적으로 깊이 있게 탐구하여 '철학의 아버지'로 불리는 그리스의 철학자 탈레스(Thales, B.C. 624-545)는 '만물의 근원은 물'이라고 하며 우주의 근원과 자연의 이치를 물로 설명하였다. 중국 초나라의 사상가로 알려진 노자(老子)는 《도덕경(道德經)》제 8장에서 “최고의 선(善)은 물과 같다. 물은 만물을 이롭게 하는 데 뛰어나지만 다투지 않고, 모든 사람이 싫어하는 곳에 머문다. 그러므로 도에 가깝다(上善若水, 水善利萬物而不爭, 處 衆人之所惡, 故幾於道).”라고 하였다(두산백과, 2020). 프랑스의 철학자인 가스통 바슐라르 (Gaston Bachelard 1884-1962)는 물에 대한 정화의 의미를 강조하였다. 투명하고 반영되는 성 질로 인해 순수를 상징하며, 생명을 주고, 육체 또한 깨끗하게 해준다. 하나의 예로써 신화 속에서 깨끗하고 신선한 물로 목욕을 하면 젊어진다는 것은 정화의 의미와 함께 치유를 희 망하는 바람도 담겨 있다. 또한 물은 다른 원소들에 비해 깊이와 관련되어 있는데 고여있 는 물의 깊이가 깊을수록 어둠의 속성을 지니며, 그렇기에 물은 죽음과도 연관이 있다.

우리가 살펴보고자 하는 바다는 지구 표면의 4 분의 3 을 차지하는 염수로서, 해양(海洋)이 라고도 한다. 해양의 '해(海)'는 깊고 어두운 바다 빛깔을 나타내고, '양(洋)'은 바닷물이 넓 고 길게 이어져 있는 모양을 나타낸다(두산백과, 2020). 깊고 어두운 심해, 끝없이 펼쳐지는 바다는 그 깊이를 알 수 없는 푸르름과 그 끝을 알 수 없는 광활함으로 인간에게 경외심을 가지게 한다.

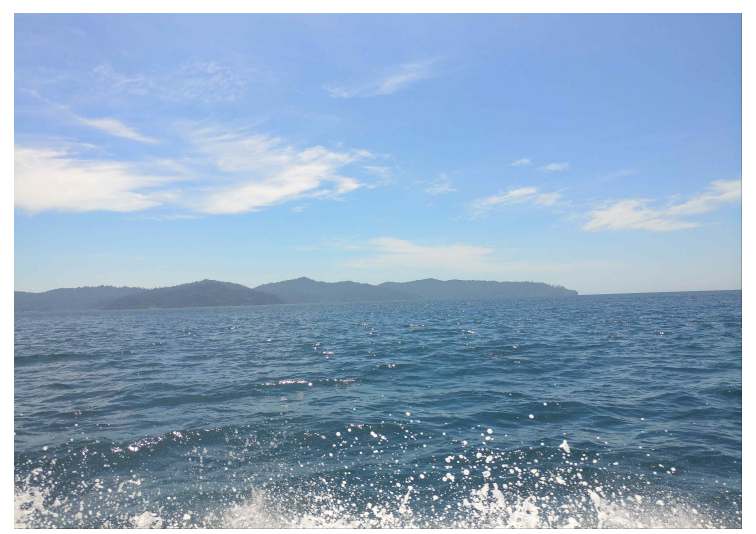

그림 1. 바다와 파도

출처. 직접 촬영 
Journal of Symbols \& Sandplay Therapy, Vol.12 No.1.

바다의 무한한 생명력과 생동감을 느낄 수 있는 것은 파도 때문이다. 대부분의 파도는 바람에 의해 만들어진다. 파도는 잔잔한 바람에 일렁이는 파랑에서부터 바다 깊은 곳에서 지진이나 화산 폭발에 의한 충격으로 발생하는 큰 너울성 파도인 쓰나미까지 그 물결의 높 이와 강도가 다양하다. 비록 파도가 약하더라도 오랫동안 지속적으로 바람이 불면 파도는 점점 높아지게 된다. 다시 말해 파도의 크기는 바람의 속도와 지속시간, 바람이 불어온 거 리에 의해 결정된다. 즉, 바람이 강하고 불어온 거리가 길수록 파도는 크게 인다. 그 외에 도 폭풍 해일에 의한 파도나 지진 해일에 의한 파도, 강력한 태풍에 의한 파도 등 다양하 게 발생한다(윤경철, 2009).

\section{2. 바다와 파도의 상징적 의미}

바다는 무한한 자유와 용감한 모험을 떠올리게 하는 동시에 헤아릴 수 없는 깊이(무의식) 를 뜻하기도 한다. 그 광대함 속에는 활기와 두려움이 들어 있다(Fontana, 2010/2011). 바다는 모성, 감정, 무의식을 상징하며, 무한한 자유, 즐거움, 생명력, 재생, 평온함, 외로움, 지구의 자궁, 위대한 모성, 태모 그리고 여성 등을 나타낸다. 바다에 치는 파도는 열정의 힘, 감정 과 무의식의 상태를 나타낸다. 물은 생명의 원천이고 바다가 원초의 물을 의미하므로 바다 는 혼돈, 끝없는 운동, 생명의 원천을 상징하며 풍요와 다산의 상징인 동시에 죽음을 상징 하기도 한다(이근매, 아오키도모코, 2017).

물이 정적이라면 바다는 동적이고 율동적이다. 달과 맺어진 조수의 운동과, 바람과 맺어 진 파도의 운동으로 바다의 역동성을 느낄 수 있다. 파도는 변화를 대동하는 항구성과 순 간이 뚜렷이 드러나는 영원성을 상징한다(양성모, 1992).

고요하고 잔잔하게 일렁이는 파도는 안정감과 평온함을 주지만, 거대하고 거친 파도는 두려움의 대상으로 생각되기도 한다. 이러한 두려움이 신앙으로 발전되어 건강과 장수, 번 영에 대한 기원을 용왕에게 빌었다. 거센 파도의 힘에 놀란 사람들이 해난 사고를 미리 막 기 위해 정성을 다해 음식을 차려놓고 치성을 드렸다. 이때 파도는 공포와 불안, 위험 등을 상징한다(정지인, 2005).

바다에 파도를 일으키는 바람은 우주의 호흡을 상징하고, 생명을 유지하며 분열하지 않 도록 보호하는 영(靈)의 힘을 상징한다. 그래서 바람이 끈, 실, 그물 등과 연관된다. 바람은 세계와 세계를, 이 세상에 존재하는 모든 것들을 연결한다. 하지만 손에 잡히지 않는 것, 실체가 없는 것, 잡아두기 어려운 것을 나타내기도 한다(Cooper, 1978/2007). 이처럼 바람은 하늘의 기운, 즉 우주의 숨을 상징하며, 바람이 약할 때는 인간적 미덕으로 표현되지만, 세차게 부는 모래바람이나 떠돌이 바람 등은 악덕의 상징으로 여겼다((두산백과, 2020) ‘풍파(風波)'에서의 바람은 고난을 상징하기도 하며, 바람에 의해 만들어지는 파도는 멈추지 
않고 움직이는 물로서 인생의 영고성쇠(㮡枯盛衰), 변화를 상징하며, 환영(幻影), 허망, 동요 를 나타낸다고 하였다(Cooper, 1978/2007).

\section{3. 신화와 민담에 나타난 바다와 파도의 상징}

\section{1) 고요한 바다와 격정적인 바다}

우선, 그리스 신화에 등장하는 바다의 신인 네레우스에 대해 살펴보고자 한다. 네레우스 는 고요한 바다의 신이다. 그는 온화하며 지혜롭고 거짓을 모르는 진실한 성품을 지녀 바 다의 노인이라 불린다. 네레우스는 친절하며 어느 한쪽으로 치우치지 않는 정직과 공평함 을 지녔고, 예언 능력과 지신의 모습을 자유자재로 변신시키는 능력을 갖췄다. 고대 그리스 의 서사시인 헤시오도스의 『신들의 계보』에 의하면 해원(海原) 폰토스와 대지의 여신 가 이아와의 사이에서 마음씨 고운 장남으로 태어난 네레우스는 이후 고요한 바다를 상징하게 되었다. 대양의 신 오케아노스의 딸인 도리스와 네레우스 사이에는 50 명의 아름다운 딸들 인 네레이데스가 있다. 이들은 바닷속 깊은 곳에 있는 네레우스의 궁전에서 살면서 돌고래 를 타고 다니거나 파도가 이는 바다를 긴 머릿결을 너울거리며 헤엄쳐 다니곤 했다. 이들 바다의 님페 네레이데스는 바다의 넘실거리는 물결을 상징한다고 알려져 있다(그리스로마 신화 인물백과, 2020).

네레우스가 고요한 바다의 신으로 선원들의 보호자였다면, 포세이돈은 폭풍에 요동 치는 성난 파도와 같은 격정적인 바다의 신이었다. 포세이돈은 바다, 지진, 돌풍의 신 이며 돌고래, 말 등이 대표적인 상징물이다. 그의 힘을 상징하는 삼지창은 바다에 파도 를 일으키거나 대지에 지진을 일으킨다. 하천이나 샘을 솟아나게도 하고 새로운 섬을 창조하기도 한다(위키백과, 2021). 대지를 뒤흔드는 지진과 화산 폭발은 포세이돈의 격 정적인 성품을 담고 있다. 호수처럼 잔잔하던 바다에 일순간 광풍이 몰아치고 산더미 같은 해일이 덮쳐와 모든 것을 삼켜버린다. 포세이돈은 즉흥적이고 충동적인 그저 순 간적인 감정과 느낌에 따라 행동하고, 성급하고 직선적이며 변덕스럽고 감상적이라고 알려져 있다. 포세이돈에게서 나타나는 세련되지 못한, 거칠고 투박한 면모는 폭풍, 노 도, 해일, 지진, 화산 폭발 등과 같은 대자연의 원초적인 힘을 보여준다(그리스 로마 신화와 서양 문화, 2020).

\section{2) 아름다운 바다와 파괴적인 바다}

포세이돈은 네레우스의 딸들인 50 명의 네레이데스 중 바다에서 춤을 추고 있던 암피트리 테에게 반해 청혼하였으나 암피트리테는 포세이돈의 청을 거절한다. 포세이돈은 계속 구애 하며 바다의 동물들을 동원하였는데 결국 돌고래의 설득으로 암피트리테와 결혼한다. 바다 
Journal of Symbols \& Sandplay Therapy, Vol.12 No.1.

의 아름다움을 상징하는 암피트리테는 포세이돈의 아내로서 바다의 여왕이 된다. 암피트리 테는 잔잔한 바다의 여신, 또는 폭풍우 속에서도 안전한 경로의 상징으로도 인용되었는데, 암피트리테의 목소리가 남편의 분노를 진정시키고 깊이 잠들게 하여 바다를 잔잔하게 만 들 수 있는 유일한 존재였기 때문이라고 한다(다음백과, 2021).

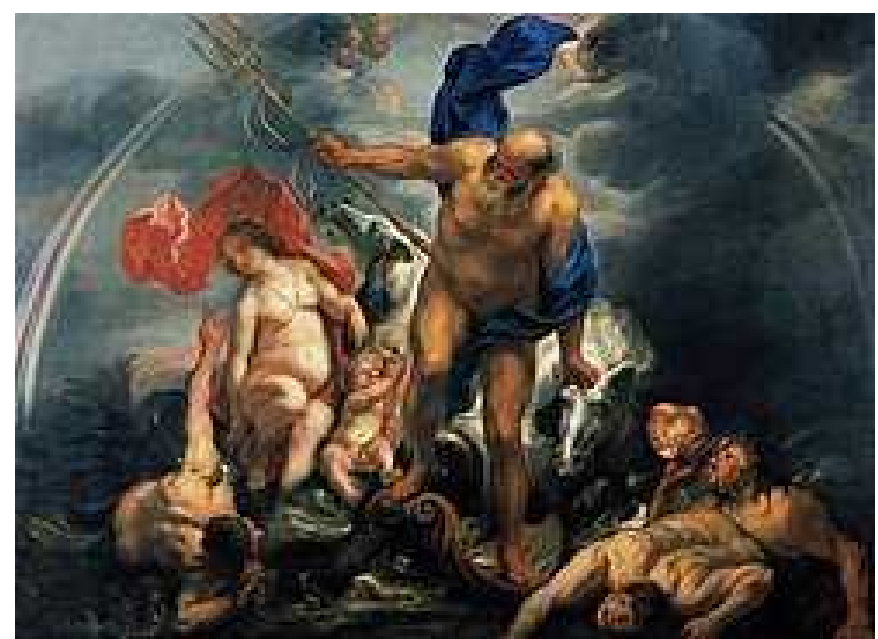

그림 2. 야곱 요르단스 〈Neptune and Amphitrite in the storm〉

출처. https://commons.wikimedia.org/wiki/File:Jacob Jordaens - Neptune and Amphitrite in the storm, 1644.jpg

포세이돈은 결혼 후에도 다른 여신이나 여인들과 바람을 많이 피웠다. 헤라가 제우스의 불륜 상대나 그 자식들을 집요하게 괴롭혔다면, 암피트리테는 혼자서 노호하며 바다를 뒤 집어 놓는 것으로 분을 풀었다고 한다. 이는 암피트리테라는 이름의 어원이 '노호하다', '아 우성치다라는 것과 관련 있다.

그리스 로마 신화에는 바다와 관련하여 파괴적인 힘으로 상징되는 스퀼라와 카뤼브디스 두 괴물에 대해서도 나온다. 오디세이아에서 스퀼라와 카뤼브디스는 바다에서 만나는 위험 한 물살이나 소용돌이를 가리키는 괴물이다.

스퀼라에 대해서 여러 가지 이야기가 전해진다. 매우 아름다운 여인이었던 스퀼라가 포 세이돈의 사랑을 받자 이를 시기한 암피트리테가 스퀼라를 독살하였다고 한다. 또 다른 설 에 따르면 스퀼라를 본 글라우코스가 첫눈에 사랑에 빠지게 되고, 그녀의 사랑을 얻기 위 해 사랑의 묘약을 구하러 키르케를 찾아간다. 글라우코스에게 반해버린 키르케는 사랑의 묘약 대신 독약을 건넨다. 결국 키르케의 독약으로 스퀼라는 머리가 6개 달리고 목은 뱀처 럼 길며 머리마다 4 개의 눈과 3 줄의 날카로운 이빨을 가진 괴물로 변한다는 이야기이다 (Liu, 2018/2020). 


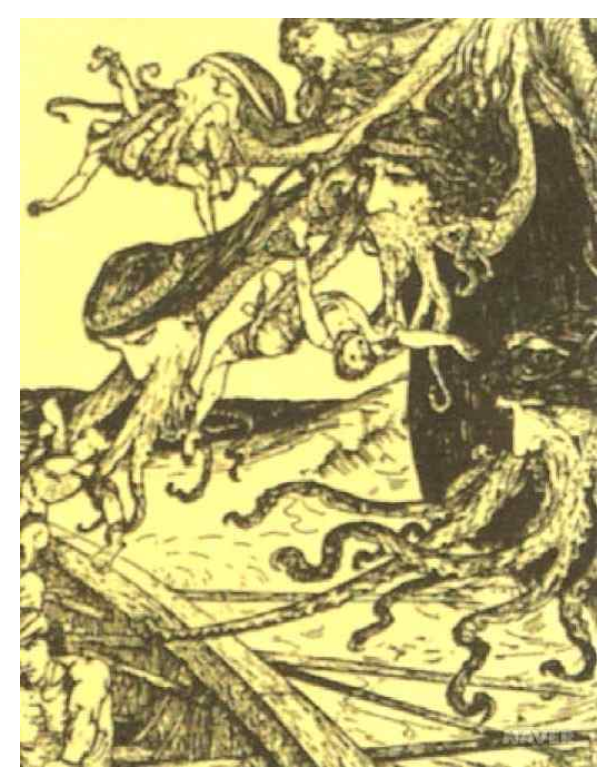

그림 3. 뱃사람들을 낚아채는 스퀼라 1930년에 출간된 그리스 로마 신화집의 삽화 출처. 벌핀치의 그리스 로마 신화 https://terms.naver.com/entry.nhn?docId=1832930\&cid=41869\&categoryId=41869

원래 아름다운 처녀였지만 키르케의 심술로 뱀 같은 괴물로 변한 스퀼라는 그로부터 높 은 절벽 위 동굴에 살면서 여섯 개의 머리에서 긴 목을 늘여 가까운 곳을 지나는 배의 뱃 사람들을 한입에 하나씩 물어 잡아먹었다. 카뤼브디스는 해면 가까이에 사는 괴물로, 하루 에 세 차례씩 바닷물이 소용돌이 속으로 빨려 들어갔다가 세 차례씩 분출되었다. 이 근처 를 지나는 배가 빨려 들어가는 소용돌이에 휩쓸리면 해신 포세이돈도 손을 쓸 수 없었다고 한다. 이렇게 무서운 괴물들이 출몰하는 곳에 이르렀을 때, 오디세우스는 그 괴물들을 찾 아내려고 주위를 엄중히 감시하게 했지만 결국 스퀼라에게 오디세우스의 부하 여섯이 끌 려갔다. 오디세우스가 그때까지 본 광경 중에 가장 무섭고도 처절한 광경이었다고 하며 동 료들이 죽어가는 것을 바라보고 그 비명을 들으면서도 속수무책일 수밖에 없었다고 하는 이야기에서 인간이 바다에 대해 가지는 공포와 두려움을 알 수 있다(벌핀치의 그리스 로 마 신화, 2020).

\section{3) 죽음으로 재탄생하거나 맞서서 극복하는 바다}

인간이 조절하지 못하는 바다의 강력한 힘과 파괴력은 우리의 고전 『효녀 심청』에서도 찾아볼 수 있다. 『효녀 심청』의 이야기에서 심봉사는 공양미 300석을 시주하면 눈을 뜨게 될 것이라는 스님의 이야기를 듣고 시주할 것을 약속하고 집으로 돌아온다. 집에 와 생각 하니 약속을 지킬 대책은 없고 한숨만 내쉬다가 심청에게 이 사실을 털어놓는다. 그때 마 
Journal of Symbols \& Sandplay Therapy, Vol.12 No.1.

침 파도가 거세 바다를 건널 수 없던 선원들은 험한 바닷길에 처녀를 제물로 바쳐 파도를 잠재우고자 한다. 처녀를 제물로 바쳐야만 거칠게 이는 성난 파도를 잦아들게 하여 바다를 건널 수 있다는 것이다. 이 소식을 전해들은 심청은 공양미 300석을 받는 대가로 제물이 될 것을 자청한다. 약속한 날이 되어 심청은 물결이 심한 인당수에 당도하자 치마를 덮어 쓰고 검푸른 바다로 몸을 던지게 되는데 그러자 파도가 멈추며 바다는 잔잔해졌다(고혜경, 2006). 여기에서 바다는 인간이 조절하지 못하는 강력한 힘, 혼돈, 파괴력 등을 나타낸다(이 근매, 아오키도모코, 2017)

거친 풍랑의 바다가 고난과 역경으로 상징되며 인간에게 두려움의 존재로 등장하지만, 『복 받으러 간 석숭이』 민담에서는 그 고난과 두려움에 맞서는 주인공을 만날 수 있다. 어릴 때 부모를 여읜 석숭은 머슴살이를 하고 살아가지만 가난한 살림은 나아질 기미가 없 었다. 이런 자신의 처지를 비관하던 석숭은 어느 날, 죽기로 결심하고 샘물에 빠져 죽으러 갔는데 한 노인이 나타나 꾸짖으며, 서천 서역국으로 가서 복을 타 오는 방법을 일러주었 다. 그리하여 석숭은 서천 서역국을 찾아 먼 길을 떠나게 되었다. 여러 사람의 도움으로 긴 여정을 거쳐 드디어 서쪽 끝에 다다랐다. 먼바다 가운데 서천 서역국이 보였지만, 깊은 바 다를 건널 일이 막막했다. 석숭은 그때 바다로 나가는 배 한 척을 발견하고 사정하여 배를 얻어 타게 되었다. 어렵게 바다를 건너던 중 갑자기 거센 풍랑이 불면서 배가 뒤집히려고 했다. 우왕좌왕하는 사람들 사이로, 이무기 한 마리가 나타났다. 석숭은 침착하게 이무기를 보며 꾸짖었다. 그러자 이무기는 석숭에게 용이 되지 못한 자신의 처지를 한탄하였다. 그 말을 들은 석숭은 이무기를 달래면서 서천 서역국에 도착하면 이무기의 사정 이야기를 해 주겠다고 약속하였고, 그 말을 들은 이무기는 크게 기빼하며 석숭을 서천 서역국으로 데려 다주었다. 천신만고 끝에 드디어 서천 서역국에 도착한 석숭은 용왕님을 만나 그동안의 사 정을 이야기하고, 복표를 받고 아내도 얻게 된다(문화원형백과 한국설화 인물유형, 2020) 이렇듯 우리의 민담에서 바다는 인간에게 고난과 역경이지만, 두려움에 도망가지 않고 맞 서며 헤쳐나가는 인간의 지혜와 용기를 함께 보여준다.

\section{4) 대극을 통합하는 사랑의 바다}

마지막으로 바다와 파도의 또 다른 상징성을 알아보기 위해 그리스 신화에 나오는 올림 포스 12신 중 하나인 미와 사랑의 여신 아프로디테에 대해 살펴보고자 한다. 헤시오도스의 『신들의 계보』에 따르면 아프로디테는 크로노스의 낫에 잘린 우라노스의 성기가 바다에 떨어져 그의 정액과 바닷물이 섞이면서 생겨난 거품에서 태어났다고 한다. '거품'을 뜻하는 고대 그리스어는 '아프로스', 아프로디테는 '거품에서 나온 여인'이라는 뜻이다. 아프로디테 는 또한 아나디오메네라는 별칭으로도 자주 불리는데 이는 '바다에서 올라온 여인'이라는 뜻이다(그리스로마신화 인물백과, 2020). 


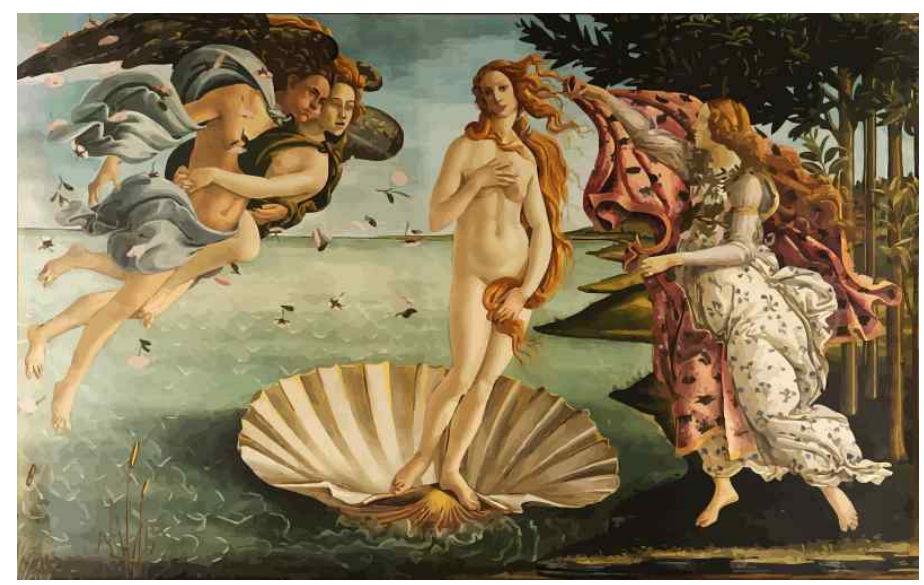

그림 4. 산드로 보티첼리 〈아프로디테의 탄생〉

출처. https://commons.wikimedia.org/wiki/File:La_nascita_di_Venere_vectorized.png

아프로디테는 하늘에서 뿌려진 씨앗을 바다의 자궁이 보듬어 잉태한 여신으로 풍성함과 우아함과 생명의 기운을 물씬 뿜어낸다. 순결, 순수, 평화를 뜻하는 천상적인 측면과 풍요 와 다산의 상징인 대지적인 면을 모두 가지고 있는 아프로디테는 두 대극적인 요소가 한 몸에 통합된 여신의 자연스러우면서도 고도로 정제된 아름다움을 모두 간직하고 있다. 두 대극적인 요소인 천상의 숭고함과 대지의 비옥함, 성과 속, 야성과 문명, 영과 육이 한 몸 에 통합된 여신이 아프로디테다. 까르르 넘어가는 웃음과 살살 녹아내릴 듯한 달콤함, 장난 기 어린 포옹과 키스, 흥겨운 놀이는 모두 여신의 것이다. 아기 같은 얼굴에서 드러나는 티 없는 천진함과 부드러움, 따뜻함과 포근함, 공기와 기분을 달뜨게 하는 가벼움과 유머가 아 프로디테의 공간에 진동한다. 들꽃같이 싱그러운 냄새와 자연스러운 접촉이 주는 따사로움, 가벼워진 공기와 말의 유희와 유혹의 예술이 어우러져 자아내는 순수한 기쁨이 여신의 선 물이다. 아프로디테를 존중하는 자세는 주변 사람들이 자기 내면의 아름다움을 발견하여 마음껏 드러내게 만들어 아름다움을 주변으로 전염시킨다. 아름다움을 자기만의 것으로 가 둬 두는 것이 아니라 가꾸고 드러냄으로써 미의 여신 아프로디테를 즐겁게 만든다. 아름다 움을 드러내는 삶이 진실하고, 진실한 사람은 아름답다. 삶이란 자기 안에 숨어있는 아름다 움을 발굴하고 드러내 세상을 아름다움으로 채워가는 과정이다(고혜경, 2006).

고요한 바다의 신 네레우스와 잔잔한 물결을 상징하는 네레우스의 아름다운 딸들 네레이 데스, 폭풍 노도의 격정적인 감정파 포세이돈과 힘들게 구애하여 얻게 된 그의 아내 암피 트리테, 사랑의 시기 때문에 아름다운 여인에서 파괴적인 바다의 괴물이 된 스퀼라와 소용 돌이 괴물 카뤼브디스를 통해 신화에 나타난 바다와 파도의 다양한 상징을 살펴보았다. 그 
Journal of Symbols \& Sandplay Therapy, Vol.12 No.1.

리고 처녀를 제물로 바쳐야 잔잔해진다는 거센 바닷속으로 몸을 던져 죽음으로 재탄생하는 사랑과 희생의 심청, 거센 풍랑이라는 고난과 역경에 지혜와 용기로 맞서서 결국 복과 사 랑하는 여인을 얻게 된 석숭을 만나보았다. 하늘에서 뿌려진 사랑의 정기를 바다의 자궁이 잉태하여 태어난 사랑의 여신 아프로디테에게서 자기 내면의 아름다움을 발견하여 드러냄 으로써 세상을 아름다움으로 채워가는 삶에 대해 생각해 보았다.

\section{4. 모래놀이치료 사례에 나타난 바다와 파도의 상징}

$\mathrm{Lia}$ 는 40 대 중반의 여성으로 두 자녀를 둔 엄마이자 직장인이다. 30 대 초반에 다시 학업 을 시작해 대학을 졸업하고 직장을 얻게 된 지 10 년이 되었다. 매사에 열심히 임하는 성실 함을 갖추었지만, 자신을 돌보기보다는 가족들을 돌보거나 업무적인 부분에서 주어진 역할 에 충실히 하고자 하는 경향이 지나쳐 에너지가 고갈되고 많이 소진되어 보였다. Lia는 자 신의 아버지가 가정은 돌보지 않으면서 항상 자신의 꿈과 열정, 아내와 가족이 아닌 다른 사랑을 좇아 평생을 보냈으며, 자신이 원하는 대로 되지 않으면 가족에게 충동적으로 분노 를 표현하였다고 했다. Lia는 아버지의 그런 이기적인 방식과 무책임한 삶이 얼마나 가족 을 힘들게 하는지를 겪어 왔기 때문에 자신은 가족을 살뜰히 돌보며 부모의 역할을 잘 해 내고 싶다고 했다. 어린 시절을 바닷가 마을에서 살다가 가정의 형편이 어려워져 도시로 이사를 오게 된 Lia는 그 이후로 늘 바다를 동경해왔다. 어린 시절부터 반복해서 꾼 꿈이 바다에 관한 꿈이라 하여 회기 중 바다 꿈과 관련한 꿈 분석이 이루어졌다. 분석심리학에 이론적 토대를 둔 모래놀이치료에서는 인간의 무의식을 탐색하는 과정으로 꿈 분석을 중 시하는데, 꿈을 통해서 인간 무의식의 심오한 상징을 빈번히 대면하게 되기 때문이다(황화 란, 2020). 꿈의 언어는 상징이다. 무의식은 꿈에서 상징으로 드러나고 꿈을 이해하기 위한 열쇠는 바로 상징에 대한 지식이다(Boa, 1988/2004). Lia의 사례에서 바다에 관한 꿈을 다룬 회기와 모래놀이치료 회기 중에 바다가 출현한 회기를 중심으로 바다와 파도의 상징을 분 석해본다.

\section{1) 바다에 관한 꿈}

$\mathrm{Lia}$ 가 반복해서 꾸는 꿈은 바다를 찾아 이리저리 헤매는 꿈이라고 했다.

“꿈속에서 나는 바닷가에 있어요. 검은 바위 위를 이리저리 옮겨가며 조금이라 도 더 바다 가까이로 다가서려 해요. 파도가 발밑에 부서져요. 아, 바다예요!! 저 만치서 출렁이며 넘실대다가 하얀 물보라를 일으키며 부서지는 파도를 하염없이 
바라보며 앉아 있어요. 눈물이 흘러요. 그런데 해가 뉘엿뉘엿 지고 밤이 되고 있 어요. 완전히 어두워지기 전에 집으로 가야 해요. 아쉽지만, 좀 더 앉아 있고 싶 지만... 툭툭 털고 일어나요. 어둑어둑해져서 집으로 향하는 버스를 타고 돌아와 요."

그림 5는 Lia가 만든 모래 상자이다. 모래 상자의 중앙에 있는 여자 피규어가 바위에 홀 로 걸터앉아 하염없이 바다를 응시하고 있다. 모래 상자의 오른쪽 앞에는 큰 산이 있고, 왼 쪽 뒤로 바다가 펼쳐져 있다.

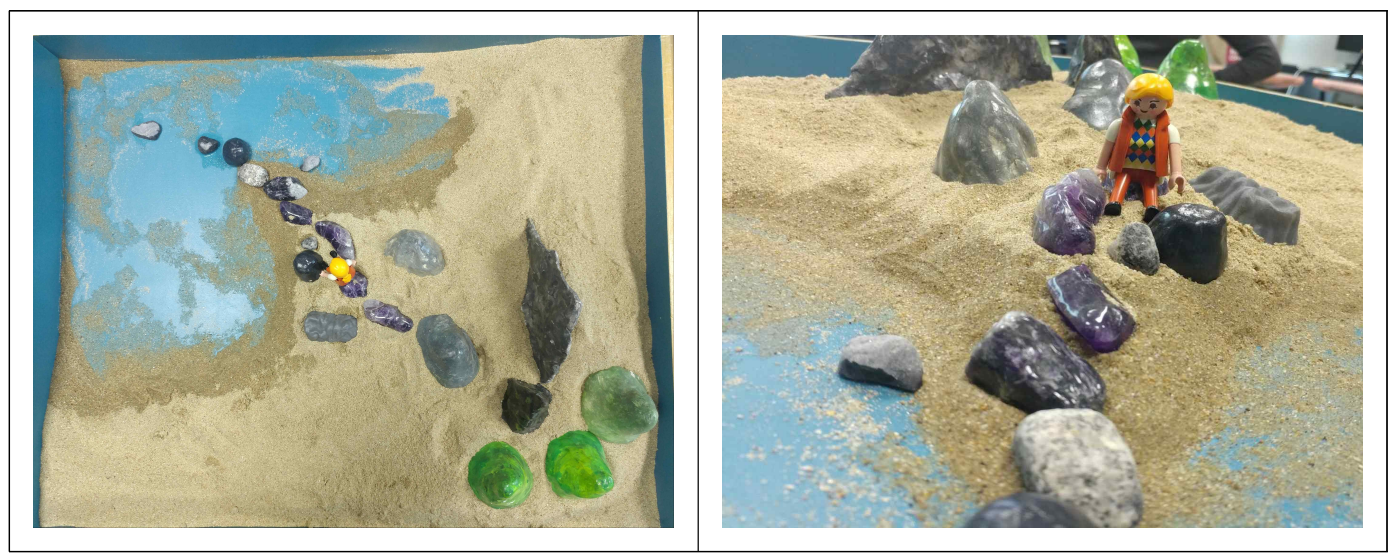

그림 5. 꿈 분석 시 바다에 관한 꿈을 표현했던 모래 상자

Lia는 꿈을 연상하며 자신이 때때로 무엇을 해야 할지, 어디로 가야 할지, 무엇을 느끼는 지조차 알 수 없고 생명의 감각도 마비되어버린 것 같을 때, 삶의 나침반도 이정표도 없는 그 압도적인 외로움을 느낄 때 바다를 찾는다고 말하였다. 끝없이 펼쳐진 드넓고 광활한 바다를 마주하고 바다의 파도 소리를 들으면 Lia는 지금까지 단 한 번도 만나보지 못한 세 계의 열림이 일어난다고 하였다. 수천 년 수만 년 동안 잠자고 있던 무언가가 깨어나는 것 같은 순간, 태곳적 원형인 바다와의 만남이 좋다고 하였다. 바다가 들려주는 파도 소리와 바람이 전해주는 바다 내음이 그녀의 마음을 편안하게 만들었고, 바다와 이야기를 나누면 위로받는 느낌이 들었다고 하였다.

Turner(2005/2009)는 모래놀이에서 바다는 정신적인 특성의 도착과 출발의 장소라고 하였 다. 험준하거나 울퉁불퉁한 해안선은 부드러운 해안선과는 다른 의미를 지니는데, 튀어나왔 거나 반도의 모양을 한 해변은 변화를 향한 정신적인 진보를 뜻한다고 했다. 이것은 정신 적인 발전 가능성을 풍요하게 하는 깊은 곳을 향한 침투가 된다고 설명하였다. 위의 모래 
Journal of Symbols \& Sandplay Therapy, Vol.12 No.1.

상자에서 볼 수 있듯이 크고 작은 바위들이 바다 깊은 곳으로 이어져 Lia의 내면이 깊은 바 다의 무의식적 측면과 연결되어야 함을 보여주고 있다.

모래 상자에 나타난 바다와 모래의 경계를 살펴보면 거친 파도의 흔적이 느껴진다. 물을 사용하지 않은 모래 상자인데 신비롭게도 사진 속의 모래 상자는 빛의 음영으로 인해 젖은 바다처럼 보인다. 그래서 홀로 침묵하며 침잠해 보이는 여자의 뒷모습이 더욱 쓸쓸하고 우 울하게 느껴진다.

사람들은 자기 자신과 마주할 때는 홀로이다. 우리의 태어남이 관계의 탯줄을 끊는 것이 라면, 우리의 삶은 의미를 엮어가는 관계 맺음의 작업이다. 관계 맺음은 이렇게 모든 사람 이 당연히 알고 있는, 그래서 더 이상 아무런 의미도 없는 진부한 일상의 덫'으로 변해버 린다. 그렇기 때문에 접촉의 단절에서 오건 아니면 접촉의 과다에서 오건, Lia는 지금 이 실 존의 고독을 견뎌 내야 한다. Lia는 지금까지 아무 생각 없이 받아들였던 부모의 생각, 세대 의 가치, 사회의 제도와 관습, 결혼의 체계, 어린 시절 트라우마에 의해 '잠들어 있던' 자신 을 깨워 놓는 실존의 고독과 대면해야 한다. 혼자라는 사실을 깨닫고, 집단 문화로부터 받 은 무거운 짐을 벗어버리고자 하는 $\mathrm{Lia}$ 의 '실존적 일탈'은 아주 자연스럽고 반가운 일이다. 자신을 발견한 이들은 홀로 서고자 하고, 자유로워지고자 한다. 따라서 Lia는 홀로 있는 시 간이 필요하다.

바닷가는 두 세계, 곧 육지와 바다가 만나는 곳으로 인간 정신의 두 영역인 의식과 무의 식의 영역을 상징하므로 바닷가에 대한 꿈은 내담자에게 무의식과 친숙해지고 무의식의 영 역을 탐구할 것에 대한 권유일 수 있다(Ackroyd, 1993/1997). 자신의 내면을 돌보지 않고 의 식적 영역에서 주어진 역할에만 몰두했던 $\mathrm{Lia}$ 에게 바다는 자신을 돌보는 시간이 필요함을 알려 주는 깊은 내면의 신호를 보내지만, 꿈속에서의 그녀는 아쉬워도 어두워지기 전에 집 으로 가야 한다고 일어선다. 외적 세계든 내적 세계든 중심을 잡지 못하고 한쪽으로 치우 치는 것은 무의식적 요소들이 통합되는 것에 방해요인이 된다(이여름, 2018). 홀로 고요히 침잠하며 자기와의 대화가 더 필요해 보이지만, 자기를 돌보기보다 가족을 돌보기 위해 그 녀는 집으로 향하는 버스를 타고 돌아가고 있다.

$\mathrm{Lia}$ 는 모래놀이치료의 꿈 분석 과정에서 자신의 모래 상자에서 보여지는 거친 파도의 흔 적을 바라보며 우울감과 분노감을 표현하였다. 자신의 자연스러운 감정, 그 자체로 좋지도 나쁘지도, 타당하지도 타당하지 않은 것도 아니라는 것을 알지만 '착한 여자'에게 우울과 분노란 부적절하며 드러내어서는 더욱 안 되는 감정이라 여겼던 자신을 발견하였다. 분노 를 느끼면 침묵했고 눈물로 삼키거나 자책하거나 아니면 상처로 묻어버렸다고 하였다. 우 리가 사회적 기준에 맞춘 자신의 페르소나와 지나치게 동일시될수록 다양한 감정은 억압되 고 우리의 내면이 눈물을 흘리게 된다(성은경, 2015). 
Lia는 망망대해 끝없이 펼쳐진 바다를 바라보며 처연하게 앉아 있노라면 감정의 파도가 휘몰아쳐 옴이 느껴졌다고 했다. 파도의 움직임이 그녀 감정의 일렁임으로 그동안 살면서 침묵하며 묻어둔 분노를 흔들어 깨워 삼켰던 울분을 토해내게 하였다. 좋은 딸로서, 좋은 엄마로서, 좋은 아내로서, 커리어우먼으로서 '만들어진 페르소나'에 모든 에너지를 쏟으며 주위 사람들을 보살피지만, 정작 자기 자신은 돌보지 않아 피폐해진 삶에 대한 분노였을 것이다. 선의 페르소나에 의하여 제외되고 억제된 감정과 정신이 의식세계에서 떨어져 나 가 무의식의 특징을 이룰 때 분열의 위기, 자기 자신의 전체성으로부터의 소외를 겪게 된 다(이부영, 1998).

$\mathrm{Lia}$ 는 꿈 분석 과정에서 바닷가에 홀로 앉아 파도를 마주하며 감정과 생각을 모았던 시 간에 집중하였다. 바다에서는 일상에서 그 누구에게도 보이지 못한 묵은 감정들을 꺼낼 수 있었다고 했다. 꿈 분석 과정에서 분노와 슬픔을 재경험하며 몇 년씩 묵혔던 부정적 정서 와 마주하면서, 그녀는 자신 스스로 상처받았고 부모님의 지나친 요구와 기대에 부응하는 삶을 살았다며 자신의 삶을 되돌아보았다.

거센 폭풍우가 몰아친 다음 바다가 정화되어 더 푸르고 평온해지는 것처럼, 자신의 울분 과 만나고 억눌러왔던 감정의 소용돌이를 경험하게 되면 묵혔던 울분의 자리에 다시 새롭 게 시작할 수 있는 에너지가 채워지게 된다. 그렇게 새로이 에너지를 채우고 집으로 돌아 가게 하는 원동력은 바로 사랑일 것이다. 사랑과 미의 여신 아프로디테적 특성은 일상의 삶을 윤택하게 하고 정제된 아름다움으로 채워가는 것으로 그것이 바로 여신의 예술이고 사랑이라고 했다(고혜경, 2006). 쌓였던 것을 버리고 새로운 에너지로 충만하여 기꺼이 일상 으로 돌아감을 선택한다는 것을 Lia의 꿈은 보여준다. 그리고 꿈을 통해 나를 가꾸는 삶, 진 정한 자기를 돌보는 삶으로 돌아가라고 알려 준다. 자신에게 소중함이 무엇인지 인식하고 표현하고 자유롭게 선택해 기꺼이 책임지는 삶을 살도록 격려한다. 지난날 상처를 아물게 하는 사람은 바로 자신임을, 그리고 자신을 사랑하고 자신의 사랑을 기다리는 사랑하는 사 람들이 있다는 것을 일깨워 준다.

\section{2) 모래놀이치료 상자에 나타난 바다}

다음은 Lia의 모래놀이치료 과정에서 나타난 모래 상자이다(그림 6). 

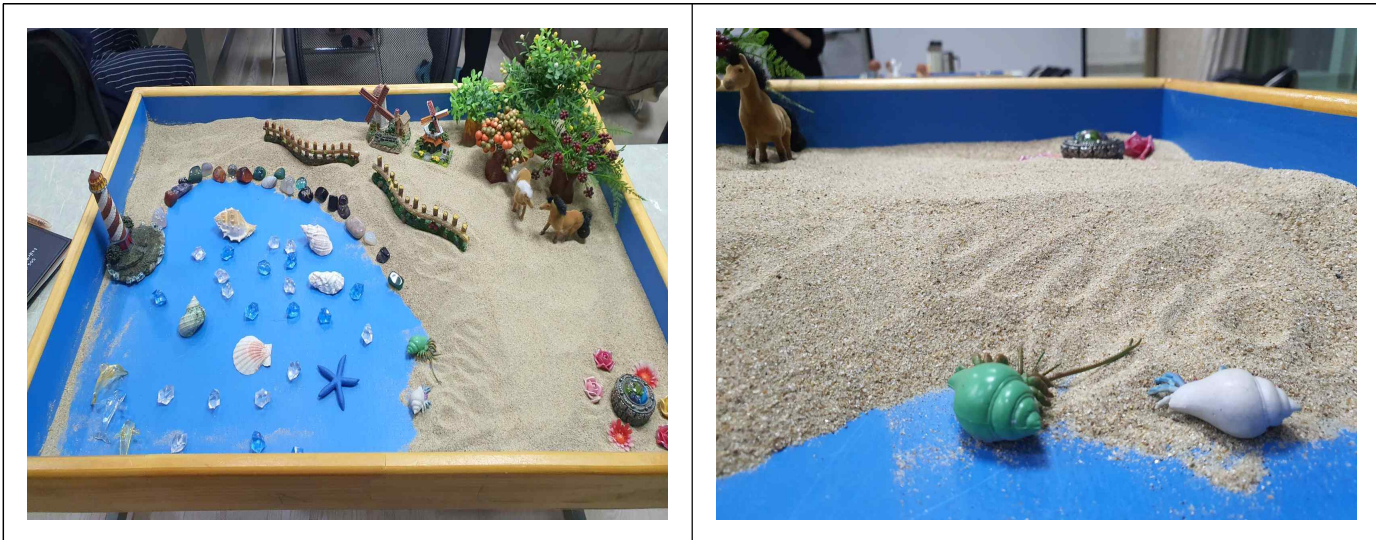

그림 6. 바람 부는 언덕과 바다를 표현했던 모래 상자

"바람 부는 언덕이에요. 바람이 많이 부는 언덕이라 모래를 높게 쌓고 싶었어 요. 바람이 많이 부니 풍차도 놓았구요. 바람이 부는 높은 언덕에서 말을 타고 달 리면 시원할 것 같아요. 바다가 저 아래 시원하게 내려다보여요. 지금은 바다가 잔잔해 보이지만 워낙 바람이 많이 부는 곳이라 언제 높은 파도가 칠지 몰라서 울타리를 세워두었어요. 저 먼바다에는 엄마 돌고래가 두 마리의 새끼 돌고래를 데리고 놀러 나왔어요. 소라게 두 마리가 막 해변 위로 올라오고 있어요. 겁쟁이 라서 조금만 놀라도 소라 속으로 쏙 들어가겠지만, 지금은 마음먹고 저곳으로 가 려고 하네요. 뮌가 소중하고 귀한 것이 있는 이곳으로요. 소라게에게는 그 여정이 무척 길 것 같지만, 그래도 묵묵히 갈 것 같아요."

$\mathrm{Lia}$ 가 만든 모래 상자는 바닷가의 바람 부는 언덕이다. 바람은 우주의 호흡이고, 실, 끈, 다리인 세상과 세상을 연결하는 살아있는 모든 것과 연결하는 상징을 의미한다. 모래를 쌓 아 올려서 언덕을 높게 세워 가파른 경사를 만들었고 그 아래에는 바다가 펼쳐져 있다. 바 람을 가르며 언덕을 내달리는 두 마리의 말은 지금 나무 밑에서 쉬고 있다. 두 마리의 말 이 전속력으로 달리는 것이 아니라 나무 밑에서 쉬고 있다는 것이 인상적이다. Lia는 지금 껏 다른 이들에게 피해를 주지 않고 독립적이고 자율적인 삶을 살기 위해 누구보다 열정을 다해 말처럼 달려왔다. Lia가 처음 치료실을 방문하여 상담에 대한 기대가 무엇인지 물었을 때, "이제는 제가 하고 싶은 것을 해 보려고요."라고 했던 말이 연구자의 마음에 울림을 주 었듯 그녀의 삶이 쉬지 않고 앞만 보고 달려온 삶이었음을 알 수 있다.

언덕 위 집 아래에는 해안선을 따라 돌을 둘러놓았고, 그 위에 울타리까지, 그리고 높은 언덕을 고려하면 2 중, 3 중의 방어막이 있는 셈이다. 바다에 가까이 있고 싶으면서도, 거센 바람에 파도가 너무 높게 칠까 봐 2 중, 3 중의 경계를 세웠다. 지금 바다는 잔잔해 보이지만 
언제 불어닥칠지 모르는 높은 파도와 해일로부터 집을 안전하게 지키고 싶은 Lia의 마음이 느껴졌다. 바람이 상징하는 세상과의 연결감을 유지하면서도 높은 파도가 상징하는 감정의 동요로부터는 자신을 지키고자 했다.

또한 상자를 다 만들고 찬찬히 음미하면서 눈에 띈 것은 중앙에서 조금 아래에 있는 소 라게였다며 소라게에 주목했다. 바다에서 막 기어 나오는 작은 소라게가 꽃으로 장식된 보 석함을 향하고 있었다. 작은 소라게에게는 긴 여정이 될 수 있을 것 같지만, 담담히 그 여 정을 갈 것만 같다고 했다. 소라게의 게는 부활, 재생을 의미하기도 하며 물과 육지를 오가 므로 의식과 무의식을 넘나드는 것의 상징이기도 하다(이근매, 아오키도모코, 2017). 또한 고둥 껍데기를 집 삼아 살아가는 소라게는 성장하면 점차 큰 껍데기를 찾아서 그전의 껍데 기는 버린다. 이런 특성 때문에 사람들에게 Hermit crab(은둔자 게)로 불린다. 충동적이고 자 기중심적이며 사랑과 예술로 가족을 힘들게 했던 자신의 아버지와 같은 삶을 살지 않으려 고 Lia는 솔직한 감정을 표현하지 않았다. 큰 껍데기를 지니고 다니며 껍데기 속으로 숨어 버리는 소라게처럼 감정을 숨기며 은둔자로서의 삶을 살았다. 소라게는 자라면서 점점 더 큰 껍데기를 필요로 하는데, Lia가 바다를 찾는 과정이 마치 작은 소라 껍데기를 버리고 조 금 더 큰 껍데기를 찾는 여정과도 같았다.

2중, 3중의 울타리를 쳐 놓는다고 하여도 깊은 바닷속 무의식은 작은 소라게를 전령으로 보내어 아직은 모래 상자의 한 귀퉁이에 자그마하게 자리하고 있는, 자기를 상징하는 꽃으 로 장식된 보석함의 존재를 알려 주었다. 작은 소라게는 내면 깊은 곳에 있는, 반짝이는 보 석이 들어 있는 보석함을 어서 열어달라고 말하는 듯했다. 자기를 상징하는 보석함의 존재 는 Lia의 자기인식 과정의 시작이다. 자기인식이란 무의식의 내용들을 인식하는 과정이며, 인식은 지적인 의식일 뿐 아니라 감정적인 통찰이라는 점에서 "깨달음"의 과정이다(성은경, 2015). 소라게의 여정은 자기인식과 깨달음으로 가는 여정이 될 것이며, 그것이 곧 개성화 과정을 향한 긴 여정의 시작이 될 것이다.

바다와 파도에 대한 상징과 $\mathrm{Lia}$ 의 사례를 연구하면서 우연히 오래전 보았던 그림 하나를 다시 접하게 되었다. 일본의 예술가 가츠시카 호쿠사이(1760-1894)의 《후지산 36경》중 가 장 유명한 작품인 <가나가와 해변의 높은 파도 아래>였다.

당장이라도 집어삼킬 듯 높게 이는 파도는 사납게 달려드는 맹수의 발톱과도 같다. 바다 위의 모든 것을 기어이 다 삼켜버리려는 듯 그 기세가 대단해 보인다. 거센 파도에 비하면 보잘것없어 보이는 작은 배에 의지한 사람들은 잔뜩 몸을 낮추고 있다. 두려움에 떨며 혼 비백산하는 모습이라기보다는 이 또한 지나갈 것을 알고 자신을 낮춤으로써 성난 파도의 출렁임과 하나가 되어 보인다. 저 멀리 파도의 한 자락처럼 보이는 후지산은 이 모든 것을 알고 있는 듯하다. 한바탕 휘몰아친 바다는 언젠가는 잔잔해질 것이고, 그 전보다 더 깊고 진한 푸르름으로 생명을 품고 자라게 하리라는 것을 다 알고 있는 듯하다. 자신을 한껏 닞 


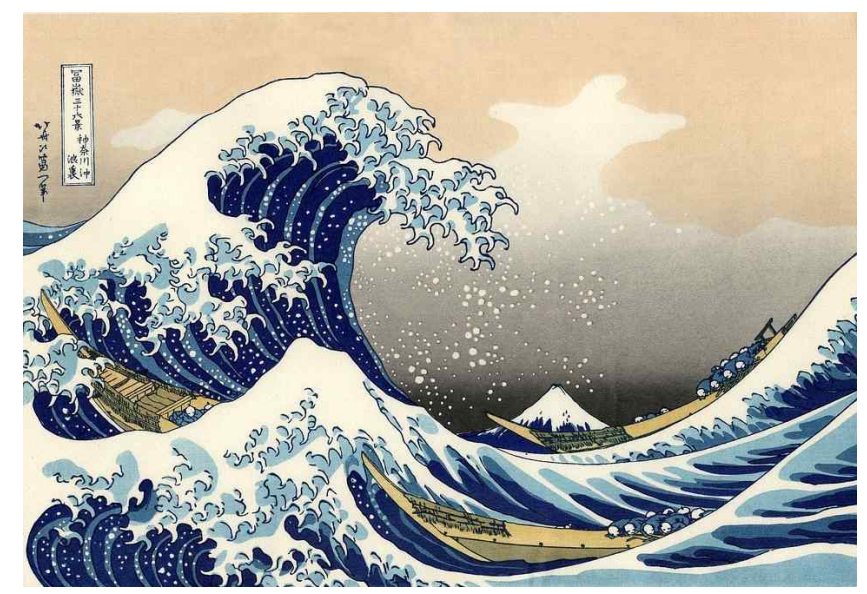

그림 7. 가츠시카 호쿠사이 〈가나가와 해변의 높은 파도 아래〉

출처. https://commons.wikimedia.org/wiki/File:Tsunami by hokusai 19th century.jpg

춤으로써 성난 파도를 겪어낸 인간은 더 단련되고 성장하며 에너지가 채워지게 되리라는 것도 다 알고 있는 듯하다. 가츠시카 호쿠사이의 작품을 보며 성난 파도, 감정의 출렁임, 깊은 자기 내면과의 조우로 자신을 더 깊이 사랑하게 된 $\mathrm{Lia}$ 의 사례가 연상되었다.

\section{III. 결 론}

바다와 파도에 대한 이끌림으로부터 시작된 이번 연구는 바다와 파도가 가지는 상징성의 의미를 깨닫고, 무의식의 바다가 주는 메시지의 의미를 밝히게 되는 계기가 되었다. 힘이 들 때마다 바다를 찾곤 했던 경험과, 현실이 아니라면 꿈에서라도 찾아 헤매던 바다, 그리 고 하염없이 바라만 보았던 그 바다와 파도의 출렁임이 $\mathrm{Lia}$ 에게 무슨 의미이며 무엇을 전하 고자 하는지에 대해 숙고해 볼 수 있었다.

$\mathrm{Lia}$ 가 일상에서 자신으로 살지 못하고 외부에서 주어진 역할에만 급급하며 내면의 소리 에 귀 기울이지 못한 순간에 무의식의 깊은 곳에서 $\mathrm{Lia}$ 를 바다로 이끈 것은 아니었을까. 그 러한 부름조차도 무시되는 어떤 날에는 꿈에서 그렇게 바다를 찾아 헤매였던 것은 아니었 을까. 바다는 의식의 세계에 살고 있던 그녀에게 무의식의 가능성과 에너지를 공급받을 수 있도록 해주는 장이 되었다(엄미연, 2014).

상징이라는 말은 그리스어 'symbolon(함께 던져진 것)'에서 파생된 것으로 본래 두 부분으 로 깨어진 막대기나 동전 등의 두 절반으로, 나중에 한 부분이 나머지 부분의 정체성을 증 명한다는 의미이다. 상징은 우리를 전체성에서 없어진 부분으로 이끌며 우리를 근원적 전 
체성과 연결시킨다(Edinger, 1972/2016). 모래 상자는 정신 외적 세계와 정신 내적 세계가 함 께 등장하는 공간으로 무의식으로부터 나온 이미지가 투사되기 때문에 무의식적 내용이 의 식화되어 내담자로 하여금 전체성에 더 가까워지게 만들고 내면에서 통합의 감정을 느끼게 한다(장미경, 2017). Lia의 모래 상자에 계속해서 나타나는 바다가 상징을 통해 그녀를 전체 성과 통합으로 이끈다는 것을 알 수 있었다.

Jung(1964/1996)은 상징성이란 정확하게 정의되거나 완전하게 설명될 수 없는 <무의식 적 측면>을 지니고 있어 완전히 설명되고 정의되기를 바랄 수 없고 마음으로 하여금 상 징을 탐구하게 하다 보면 어느새 이성으로는 파악하기 어려운 어떤 관념과 만나게 된다 고 하였다.

바다의 깊은 심연은 Lia가 일상의 삶에서 주어진 역할에만 매몰되어 진정한 자기 돌봄이 되지 않고 소진되어 가는 과정에서 $\mathrm{Lia}$ 를 불러 세워 내면 깊은 곳에 머물게 하였다. 그리고 역동적인 파도의 출렁임을 통해 그동안 삼키고 억눌러 왔던 감정의 침잠을 동요시키고 우 울의 외피를 쓴 분노를 꺼내놓게 하였다. 그리고 자신에게 상처를 준 사람이 있었다기보다 스스로 상처를 받았다고 인식하였다. 그러자 자신이 상처를 아물게 할 수 있다는, 자기 스 스로 치유할 수 있다는 것을 알게 되었다.

감정의 파도가 휘몰아침을 경험하며 응어리졌던 감정들을 흘려보낸 자리에 Lia는 사랑의 여신 아프로디테에게서 보았던 천진함과 가벼움, 자유로움과 사랑스러움을 담을 수 있게 되었고, 바다에서 사랑에 대한 에너지를 채워 삶으로 다시 돌아가는 선택을 했던 자신의 꿈을 이해할 수 있었다. 모래놀이치료와 꿈 분석을 통해 자기인식과 깨달음의 과정을 거듭 하면서 바다가 아닌 그녀의 삶에서 자신의 감정을 억누르지 않고 솔직하게 마주하려는 변 화를 보였다. 이것이 바로 자신과 자신의 삶을 사랑하며, 진정한 자기 돌봄의 삶을 당당하 게 살아가라는 바다의 메시지일 것이다.

\section{참고문헌}

고혜경 (2006). 선녀는 왜 나무꾼을 떠났을까. 서울: 한겨례출판.

성은경 (2015). 눈물: 개성화로 이그는 치유의 상징. 상징과모래놀이치료, 6(2), 47-60.

엄미연 (2014). 물: 잠재성의 상징. 상징과모래놀이치료, 5(1), 59-71.

양성모 (1992). 한국문화 상징 사전 I. 서울: 동아출판사.

윤경철 (2009). 대단한 바다 여행. 서울: 푸른길.

이근매, 아오키도모코 (2017). 상징사전. 서울: 학지사.

이부영 (1998). 분석심리학-C. G. Jung의 인간심성론. 서울: 일조각. 
Journal of Symbols \& Sandplay Therapy, Vol.12 No.1.

이여름 (2018). 자기인식과 개성화 과정의 첫 단계로서의 거울의 상징성. 상징과모래놀이치료, 9(1), 39-52.

장미경 (2017). 분석심리학적 모래놀이치료. 서울: 학지사.

장영란 (2013). 고대 그리스 신화의 물의 상징과 이미지의 변용. 인문콘텐츠, 31, 35-55.

정지인 (2005). 파도의 이미지를 형상화한 도자 조형 연구. 이화여자대학교. 석사학위논문.

황화란 (2020). 개성화 입문을 위한 영적안내자로서의 거북이 양면성이 주는 상징연구. 상징 과모래놀이치료, 11(1), 99-145.

Ackroyd, E. (1993/1997). 꿈 상징 사전(A dictionary of dream symbols). (김병준 역). 서울: 한국심리 치료연구소.

Boa, F. (1988/2004). 융학파의 꿈해석(The way of the dream). (박현순, 이창인 공역). 서울: 학지사.

Cooper, J. C. (1978/2007). 그림으로 보는 세계 문화 상징 사전(An illustrated encyclopedia of traditional symbols). (이윤기 역). 서울: 까치글방.

Edinger, E. F. (1972/2016). 자아발달과 원형(Ego and archetype). (장미경 역). 서울: 학지사.

Eliade, M. (1952/1998). 이미지와 상징(Images et Symboles). (이재실 역). 서울: 까치.

Fontana, D. (2010/2011). 상징의 모든 것(The new secret language of symbols). (공민희 역), 서울: 성균 관대학교 출판부.

Jung, C. G. (1964/1996). 인간과 상징(Man and his symbols). (이윤기 역). 경기: 열린책들.

Liu, X. (2018/2020). 세계 괴물 백과(驚奇與怪異:域外世界怪物志). (이지희 역). 경기: 현대지 성.

Turner, B. A. (2005/2009). 모래놀이치료 핸드북(The handbook of sandplay therapy). (김태련 외 15인 공역). 서울: 학지사.

\section{Web sites}

“네레우스-바다의 신” 그리스로마신화 인물백과.

https://terms.naver.com/entry.nhn?docId=3397678\&cid=58143\&categoryId=58143(2020년10월25 일 인출).

“바다" 두산백과. https://www.doopedia.co.kr(2020년10월25일 인출).

“바람” 두산백과. https://www.doopedia.co.kr(2020년10월25일 인출).

“복 받으러 간 석숭이” 문화원형백과 한국설화 인물유형.

https://terms.naver.com/entry.nhn?docId=1783632\&cid=49258\&categoryId=49258)(2020년10월25 일 인출).

“상선약수” 두산백과. https://www.doopedia.co.kr(2020년10월25일 인출).

“스퀼라와 카뤼브디스” 벌핀치의 그리스 로마 신화. 
https://terms.naver.com/entry.nhn?docId=1832930\&cid=41869\&categoryId=41869(2020년10월20 일 인출).

“아프로디테-올림포스 12신” 그리스로마신화 인물백과.

https://terms.naver.com/entry.nhn?docId=3397989\&cid=58143\&categoryId=58143(2020년10월25 일 인출).

“암피트리테” 다음백과. https://100.daum.net/encyclopedia/view/b14a4098a(2021년3월24일 인출).

“포세이돈-폭풍노도의 바다" 그리스 로마 신화와 서양문화.

https://100.daum.net/encyclopedia/view/155XX51600012(2020년10월20일 인출).

"Poseidon" 위키백과. https://en.wikipedia.org/wiki/Poseidon(2021년3월27일 인출).

투고일 : 2021. 03. 30

수정인 : 2021. 06. 18

게재확정일 : 2021. 07. 01 